Atmos. Chem. Phys., 10, 8783-8801, 2010

www.atmos-chem-phys.net/10/8783/2010/

doi:10.5194/acp-10-8783-2010

(C) Author(s) 2010. CC Attribution 3.0 License.

\title{
Observations of $\mathrm{OH}$ and $\mathrm{HO}_{2}$ radicals over West Africa
}

\author{
R. Commane ${ }^{1, *}$, C. F. A. Floquet ${ }^{1, * *}$, T. Ingham ${ }^{1,2}$, D. Stone ${ }^{1,3}$, M. J. Evans ${ }^{3}$, and D. E. Heard ${ }^{1,2}$ \\ ${ }^{1}$ School of Chemistry, University of Leeds, LS2 9JT, UK \\ ${ }^{2}$ National Centre for Atmospheric Science, University of Leeds, LS2 9JT, UK \\ ${ }^{3}$ Institute for Climate \& Atmospheric Science, School of Earth \& Environment, University of Leeds, LS2 9JT, UK \\ * now at: School of Engineering \& Applied Sciences, Harvard University, Cambridge, USA \\ ** now at: National Oceanography Centre, University of Southampton, Southampton, UK
}

Received: 11 February 2010 - Published in Atmos. Chem. Phys. Discuss.: 18 March 2010

Revised: 14 August 2010 - Accepted: 10 September 2010 - Published: 17 September 2010

\begin{abstract}
The hydroxyl radical $(\mathrm{OH})$ plays a key role in the oxidation of trace gases in the troposphere. However, observations of $\mathrm{OH}$ and the closely related hydroperoxy radical $\left(\mathrm{HO}_{2}\right)$ have been sparse, especially in the tropics. Based on a low-pressure laser-induced fluorescence technique (FAGE - Fluorescence Assay by Gas Expansion), an instrument has been developed to measure $\mathrm{OH}$ and $\mathrm{HO}_{2}$ aboard the Facility for Airborne Atmospheric Measurement (FAAM) BAe-146 research aircraft. During the African Monsoon Multidisciplinary Analyses (AMMA) campaign, observations of $\mathrm{OH}$ and $\mathrm{HO}_{2}\left(\mathrm{HO}_{\mathrm{x}}\right)$ were made in the boundary layer and free troposphere over West Africa on 13 flights during July and August 2006. Mixing ratios of both $\mathrm{OH}$ and $\mathrm{HO}_{2}$ were found to be highly variable, but followed a diurnal cycle: $\mathrm{OH}$ varied from 1.3 pptv to below the instrumental limit of detection, with a median mixing ratio of $0.17 \mathrm{pptv}$. $\mathrm{HO}_{2}$ varied from $42.7 \mathrm{pptv}$ to below the limit of detection, with a median mixing ratio of 8.0 pptv. A median $\mathrm{HO}_{2} / \mathrm{OH}$ ratio of 95 was observed. Daytime OH observations were compared with the primary production rate of $\mathrm{OH}$ from ozone photolysis in the presence of water vapour. Daytime $\mathrm{HO}_{2}$ observations were generally reproduced by a simple steady-state $\mathrm{HO}_{x}$ calculation, where $\mathrm{HO}_{\mathrm{x}}$ was assumed to be formed from the primary production of $\mathrm{OH}$ and lost through $\mathrm{HO}_{2}$ self-reaction. Deviations between the observations and this simple model were found to be grouped into a number of specific cases: (a) within cloud, (b) in the presence of high levels of isoprene in the boundary layer and (c) within a biomass burning plume. $\mathrm{HO}_{2}$ was sampled in and around cloud, with significant short-lived reductions of $\mathrm{HO}_{2}$ observed. Up to 9 pptv of
\end{abstract}

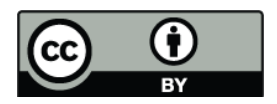

Correspondence to: D. E. Heard (d.e.heard@leeds.ac.uk)
$\mathrm{HO}_{2}$ was observed at night, with $\mathrm{HO}_{2}$ above 6 pptv observed at altitudes above $6 \mathrm{~km}$. In the forested boundary layer, $\mathrm{HO}_{2}$ was underestimated by a steady state calculation at altitudes below $500 \mathrm{~m}$ but overestimated between $500 \mathrm{~m}$ and $2 \mathrm{~km}$. In a biomass burning plume, observed $\mathrm{HO}_{2}$ concentrations were significantly below those calculated.

\section{Introduction}

The concentration of the hydroxyl radical $(\mathrm{OH})$ determines the daytime oxidative capacity of the atmosphere. Reaction with $\mathrm{OH}$ is the major removal pathway for trace gases such as methane $\left(\mathrm{CH}_{4}\right)$, carbon monoxide $(\mathrm{CO})$, Volatile Organic Compounds (VOCs) and some halocarbons, often as the first and rate-determining step in their oxidation. A deeper knowledge of the distribution of the concentration of $\mathrm{OH}$ and $\mathrm{HO}_{2}$ (collectively known as $\mathrm{HO}_{\mathrm{x}}$ ) helps our understanding of atmospheric oxidation and fast photochemical processes.

Usually the primary production pathway of $\mathrm{OH}$ in the troposphere, $P(\mathrm{OH})$, is through the photolysis of ozone $\left(\mathrm{O}_{3}\right)$ and the subsequent reaction of $\mathrm{O}\left({ }^{1} \mathrm{D}\right)$ with water vapour (Ehhalt, 1999):

$$
\begin{aligned}
& \mathrm{O}_{3}+h v(\lambda<340 \mathrm{~nm}) \longrightarrow \mathrm{O}\left({ }^{1} \mathrm{D}\right)+\mathrm{O}_{2} \\
& \mathrm{O}\left({ }^{1} \mathrm{D}\right)+\mathrm{H}_{2} \mathrm{O} \longrightarrow 2 \mathrm{OH} \\
& \mathrm{O}\left({ }^{1} \mathrm{D}\right)+\mathrm{M} \longrightarrow \mathrm{O}\left({ }^{3} \mathrm{P}\right)+\mathrm{M}
\end{aligned}
$$

The fraction of $\mathrm{O}\left({ }^{1} \mathrm{D}\right)$ reacting with water vapour to produce $\mathrm{OH}\left(F_{\mathrm{OH}}\right)$ rather than being quenched to $\mathrm{O}\left({ }^{3} \mathrm{P}\right)(\mathrm{R} 3)$ depends on the water vapour concentration present and is $0.1-0.15$ in

Published by Copernicus Publications on behalf of the European Geosciences Union. 
typical boundary layer conditions. From this, the primary rate of $\mathrm{OH}$ production can then be calculated as:

$$
P(\mathrm{OH})=2 J\left(\mathrm{O}^{1} \mathrm{D}\right)\left[\mathrm{O}_{3}\right] F_{\mathrm{OH}}
$$

$\mathrm{OH}$ is quickly converted to the hydroperoxy radical $\left(\mathrm{HO}_{2}\right)$ by reaction with CO (Weinstock, 1969):

$$
\begin{aligned}
& \mathrm{OH}+\mathrm{CO} \longrightarrow \mathrm{H}+\mathrm{CO}_{2} \\
& \mathrm{H}+\mathrm{O}_{2} \stackrel{\mathrm{M}}{\longrightarrow} \mathrm{HO}_{2}
\end{aligned}
$$

The reaction of $\mathrm{OH}$ with VOCs produces peroxy radicals $\left(\mathrm{RO}_{2}\right)$, which, in the presence of NO (nitric oxide), leads to the formation of $\mathrm{HO}_{2}$. $\mathrm{NO}$ is also important as it rapidly recycles $\mathrm{HO}_{2}$ to form $\mathrm{OH}$, allowing $\mathrm{OH}$ and $\mathrm{HO}_{2}$ to be considered as a combined $\mathrm{HO}_{\mathrm{x}}$ family. The ultimate fate of the $\mathrm{HO}_{\mathrm{x}}$ radicals is the formation of water soluble species such as $\mathrm{H}_{2} \mathrm{O}_{2}$ (through $\mathrm{HO}_{2}$ self reaction) or $\mathrm{HNO}_{3}$ (through the reaction of $\mathrm{NO}_{2}$ with $\mathrm{OH}$ under high $\mathrm{NO}_{\mathrm{x}}$ conditions), both of which can be subject to wet or dry deposition.

Tropical regions with high levels of solar irradiation, and often high humidity, have the highest production rates of $\mathrm{OH}$ (Bloss et al., 2005). The presence of high concentrations of $\mathrm{OH}$ and large surface areas allow tropical regions to dominate global oxidation of long-lived species. The rate of oxidation of $\mathrm{CH}_{4}$ by $\mathrm{OH}$ is also highly dependent on temperature and $80 \%$ of this important greenhouse gas is oxidised in the tropical troposphere (Bloss et al., 2005). The tropics also contain large regions of forest, which are a large source of global biogenic VOCs (Fehsenfeld et al., 1992; Guenther et al., 1995), with isoprene $\left(\mathrm{C}_{5} \mathrm{H}_{8}\right)$ contributing about $40 \%$ of global VOC emissions (Guenther et al., 2006; Kesselmeier, 1999). Most biogenic emissions are controlled by solar irradiation and temperature (Kesselmeier, 1999; Fuentes et al., 2000). Global models calculate that over regions with high concentrations of biogenic VOCs, $\mathrm{OH}$ will be depleted compared to concentrations at similar latitudes (Poisson et al., 2000; von Kuhlmann et al., 2004; Lelieveld et al., 2002; Karl et al., 2007). While there have been some observations of $\mathrm{HO}_{\mathrm{x}}$ in the mid-latitudes (e.g. Heard and Pilling, 2003, and references therein), observations in the tropics have been less extensive, with a distinct focus on the Pacific ocean and American continents. In tropical marine air, $\mathrm{OH}$ mixing ratios up to $0.8 \mathrm{pptv}$ (parts-per-trillion, $10^{-12} \mathrm{~mol} \mathrm{~mol}^{-1}$ ) and $\mathrm{HO}_{2}$ mixing ratios between 2 and $45 \mathrm{pptv}$ were observed during the PEM-Tropics-A (Mauldin et al., 1999), PEMTropics-B (Tan et al., 2001) and INTEX-B (Mao et al., 2009) aircraft campaigns over the Pacific, while maximum $\mathrm{OH}$ and $\mathrm{HO}_{2}$ mixing ratios of $0.37 \mathrm{pptv}$ and $24 \mathrm{pptv}$ respectively were observed at a surface site in the North Atlantic ocean (Whalley et al., 2009). Lelieveld et al. (2008) found that mixing ratios of $\mathrm{OH}$ and $\mathrm{HO}_{2}$ observed in the presence of high concentrations of isoprene over the rainforests of Suriname were not depleted to the extent expected. $\mathrm{OH}$ mixing ratios up to 0.8 pptv and $\mathrm{HO}_{2}$ mixing ratios up to 80 pptv were observed
(Martinez et al., 2010), much higher than calculated in modelling studies (Kubistin et al., 2008).

This paper presents airborne observations of $\mathrm{OH}$ and $\mathrm{HO}_{2}$ radicals above the understudied tropical West African region. The observations were made using a Fluorescence Assay by Gas Expansion (FAGE) instrument flown aboard the BAe146 as part of the AMMA (African Monsoon Multidisciplinary Analyses) Special Observation Period 2 (SOP-2) intensive in July and August 2006. The instrument and the associated calibration procedure are described in some detail (Sect. 2). The variation of $\mathrm{HO}_{\mathrm{x}}$ with altitude is presented in Sect. 3 and is interpreted in terms of the changing chemical environment, detailed previously in Stewart et al. (2008), Capes et al. (2009) and Reeves et al. (2010). OH mixing ratios are compared to the primary production rate, while $\mathrm{HO}_{2}$ mixing ratios are compared to a simple steady-state calculation. From these comparisons, a number of interesting cases were identified for further examination. These include observations of $\mathrm{HO}_{\mathrm{x}}$ in the boundary layer over forested regions (Sect. 4.3), $\mathrm{HO}_{\mathrm{x}}$ observations in a biomass burning plume (Sect. 4.4), $\mathrm{HO}_{2}$ observed in and around cloud (Sect. 4.1) and $\mathrm{HO}_{2}$ at night (Sect. 4.2). In an accompanying paper, Stone et al. (2010) compare the $\mathrm{HO}_{\mathrm{x}}$ observations presented here with a comprehensive box model. A inter-comparison of $\mathrm{HO}_{2}$ and peroxy radicals observed on two aircraft flying close together during AMMA is discussed in AndresHernandez et al. (2010).

\section{Experimental}

The Leeds Aircraft FAGE instrument was designed to be flown aboard the BAe-146 research aircraft operated by FAAM (Facility for Airborne Atmospheric Measurements).

Fluorescence Assay by Gas Expansion (FAGE) is an onresonance low pressure laser-induced fluorescence technique for the measurement of $\mathrm{OH}$ and $\mathrm{HO}_{2}$ (Hard et al., 1984). The strong $\mathrm{A}^{2} \Sigma^{+}\left(v^{\prime}=0\right) \leftarrow \mathrm{X}^{2} \Pi_{i}\left(v^{\prime \prime}=0\right) \mathrm{Q}_{1}(2)$ transition of an $\mathrm{OH}$ molecule is excited by radiation at $\lambda \approx 308 \mathrm{~nm}$ and the subsequent fluorescence is also detected at $\lambda \approx 308 \mathrm{~nm}$. The fluorescence cell is maintained at low pressure (ranging from 1.5 Torr at $9 \mathrm{~km}$ to 2.5 Torr at sea level) to ensure the fluorescence from the $\mathrm{OH}$ molecule lasts longer than the laser excitation pulse, which allows for temporal gating of the fluorescence detection. $\mathrm{OH}$ and $\mathrm{HO}_{2}$ are detected simultaneously with two excitation axes in series. After the $\mathrm{OH}$ detection axis, $\mathrm{NO}$ is added to the air flow to titrate $\mathrm{HO}_{2}$ in the sample gas to $\mathrm{OH}$, which is detected in the $\mathrm{HO}_{2}$ axis.

$\mathrm{HO}_{2}+\mathrm{NO} \longrightarrow \mathrm{OH}+\mathrm{NO}_{2}$

The sensitivity of the instrument to $\mathrm{OH}$ and $\mathrm{HO}_{2}$ must be determined by calibration. Figure 1 shows the instrument setup. The instrumentation is installed on two $19 \mathrm{inch}$ aircraft racks, located behind the fluorescence cell sampling point with pumps located below the fluorescence cell. 


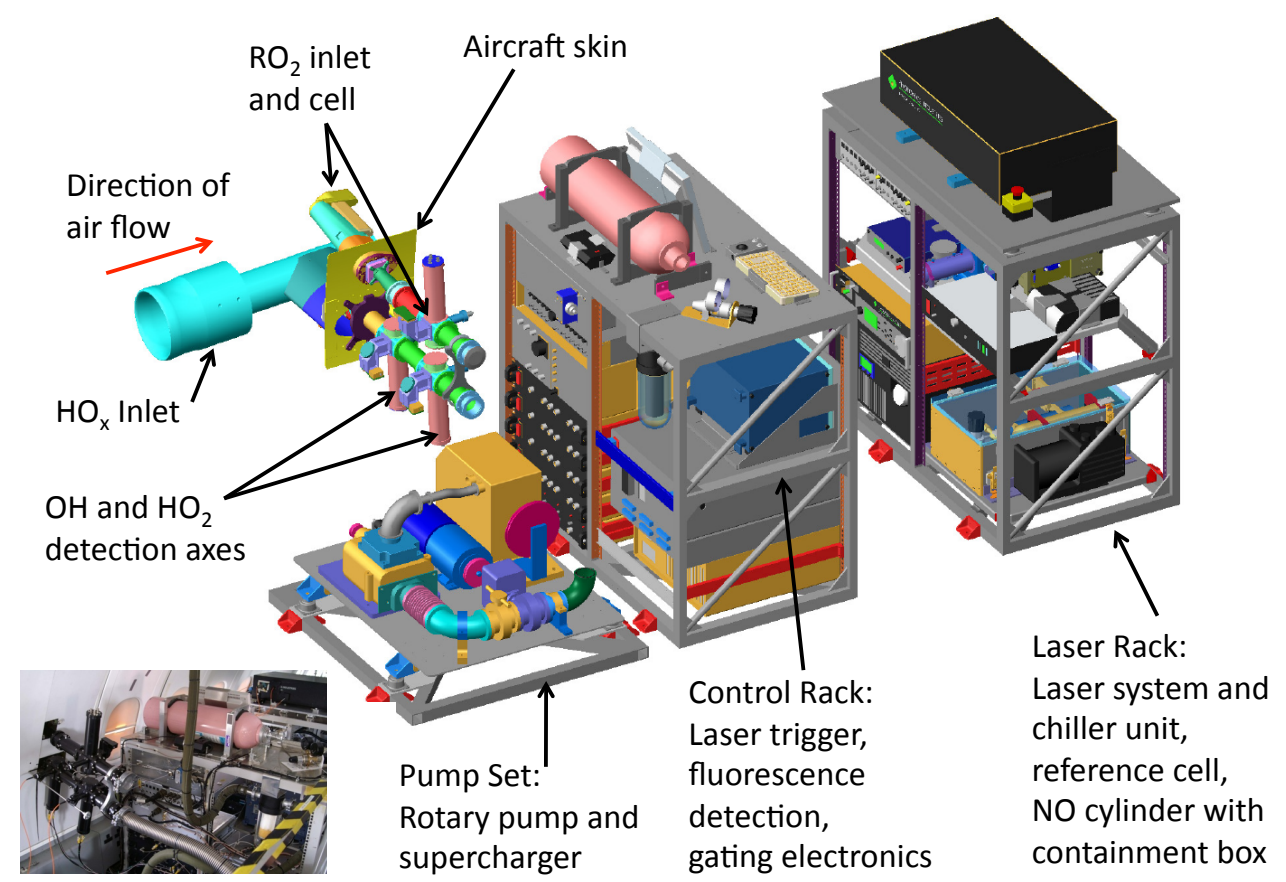

Fig. 1. Schematic outline of the Leeds aircraft FAGE instrument. Individual components are detailed in the text. The inlet delivers air to the fluorescence cell with $\mathrm{OH}$ and $\mathrm{HO}_{2}$ detection axes. The cell is maintained at low pressure (1.5-2.1 Torr) by a rotary pump backed by a supercharger (Pump Set). The fluorescence cell and pump set are not joined for clarity. The Control Rack contains the instrument computer with photon counting cards, the photomultiplier power supplies and gating electronics, the laser trigger module and a nitrogen cylinder. The

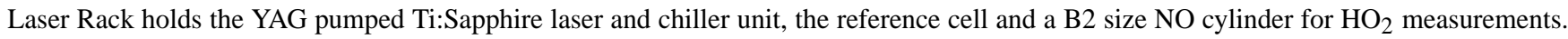
The NO cylinder is housed in a containment box designed to prevent any NO leak in the aircraft cabin in case of failure of the cylinder or regulator. Fibre optic cables (not shown) deliver the laser light from the laser to the $\mathrm{OH}, \mathrm{HO}_{2}$ and reference cells. An inlet and fluorescence cell for the detection of $\mathrm{RO}_{2}$ have been fitted but are not yet operational.

\section{1 $\mathrm{HO}_{\mathrm{x}}$ radical sampling}

Ambient air from outside the aircraft is sampled through an inlet (adapted from Eisele et al., 1997) mounted on a window blank on the starboard side of the BAe-146, close to the front of the aircraft. Using two concentric tubes with restrictions, the inlet slows the air prior to sampling, while minimising turbulence, and hence wall contact, and the associated loss of $\mathrm{OH}$ radicals.

Air is drawn in through a pinhole $(0.75 \mathrm{~mm}$ diameter $)$ to a fluorescence cell maintained at reduced pressure by a rotary pump (Leybold Trivac D25B) coupled with a supercharger (Eaton M90). In order to extend outside the aircraft skin and deliver $\mathrm{OH}$ to the excitation axis, a tube made of anodised aluminium (internal diameter $=5 \mathrm{~cm}$; length $=50 \mathrm{~cm}$ ) was added to the fluorescence cell. Characterisation tests on the cell have shown significant $\mathrm{OH}$ loss on contact with the internal tube walls, thus reducing the instrument sensitivity to $\mathrm{OH}$. No solar scattered light has been detected at either the $\mathrm{OH}$ or $\mathrm{HO}_{2}$ detection axes when the instrument was operated on the aircraft. A fluorescence cell for the detection of $\mathrm{RO}_{2}$ is shown in Fig. 1 but is not yet operational.

\subsection{Laser excitation of $\mathrm{OH}$}

Laser light at $\lambda \approx 308 \mathrm{~nm}$ was generated by a laser system consisting of a Nd:YAG (Neodymium-ion doped Yttrium Aluminium Garnet $\left(\mathrm{Y}_{3} \mathrm{Al}_{5} \mathrm{O}_{12}\right)$ DS20-532, Photonics Industries) pumped Titanium Sapphire (Ti:Sapp) laser (TU-UV $308 \mathrm{~nm}$, Photonics Industries). The YAG laser typically produces $9-10 \mathrm{~W}$ of light at $\lambda=532 \mathrm{~nm}$ at a Pulse Repetition Frequency (PRF) of $5 \mathrm{kHz}$, which is used to pump the Ti:Sapp laser. The Ti:Sapp output wavelength of $\lambda \approx 924 \mathrm{~nm}$ is selected through the use of a diffraction grating and is passed through the first of two non-linear harmonic generation stages consisting of a Cerium Lithium Borate (CLBO) crystal, generating the second harmonic at $\lambda \approx 462 \mathrm{~nm}$. A half wave plate corrects the polarisation of the light to allow the second crystal to perform sum-frequency mixing of the second harmonic $(\lambda \approx 462 \mathrm{~nm})$ with the fundamental $(\lambda \approx 924 \mathrm{~nm}$ ), producing light at $\lambda \approx 308 \mathrm{~nm}$.

Under optimal conditions, $\sim 100 \mathrm{~mW}$ of UV radiation is produced with a pulse width of $35 \mathrm{~ns}$ (Full Width Half Maximum, FWHM) and a laser linewidth of $0.065 \mathrm{~cm}^{-1}$. However, during the observations presented here, typical powers observed after adjustment varied from $30 \mathrm{~mW}$ to $50 \mathrm{~mW}$ at 


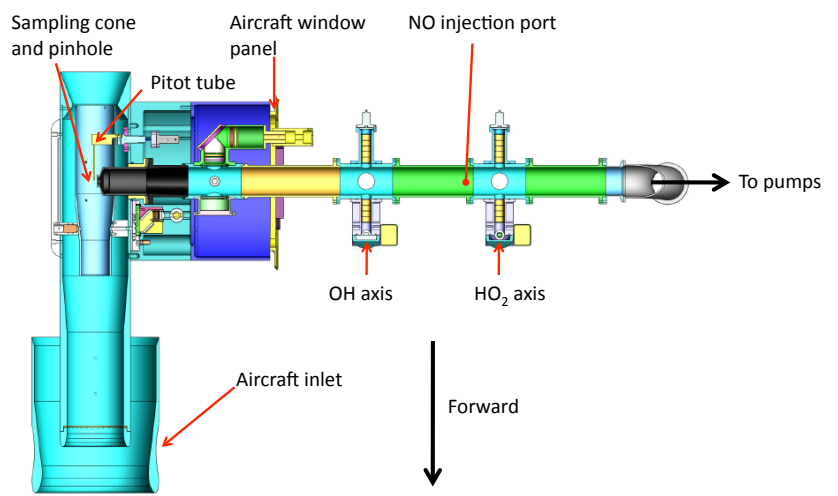

Fig. 2. Fluorescence cell for the sequential detection of $\mathrm{OH}$ and $\mathrm{HO}_{2} . \mathrm{OH}$ is detected in the first axis, with fluorescence collected perpendicular to the laser beam and sample flow. NO is then injected to titrate $\mathrm{HO}_{2}$ to $\mathrm{OH}$ and the signal due to $\mathrm{HO}_{2}$ is detected in the $\mathrm{HO}_{2}$ axis with fluorescence collection also perpendicular to the laser axis and sample flow.

$\lambda \approx 308 \mathrm{~nm}$. Dielectric coated beam splitting mirrors split the UV beam before launching the light into fibre optic cables (Oz Optics) in the ratio 60\%:36\%:4\% for use within the $\mathrm{OH}$ and $\mathrm{HO}_{2}$ axes and the reference cell respectively. Upon exiting the fibre optic cable, the laser beam entering each detection cell is collimated and baffled before intersecting the air sample. After traversing the excitation region, the beam exits the cell through another baffled arm and is directed (via a $45^{\circ}$ mirror) into a calibrated UV photodiode (UDT - 555UV, Optoelectronics), allowing real-time measurement of the laser power. The measured laser power is used to normalise the fluorescence signal for fluctuations in laser power.

\subsection{Fluorescence detection}

In the fluorescence cell (Fig. 2), the UV fluorescence is collected and passed through an interference filter (Barr Associates $\sim 50 \%$ transmission at $\lambda=308 \mathrm{~nm}$, FWHM ca. $5 \mathrm{~nm}$ centered at $\lambda=308 \mathrm{~nm}$ ). A back reflecting mirror (CVI Optics) improves the signal collection efficiency. The fluorescence signal is then focused onto the Channel Photomultiplier (CPM) (Perkin-Elmer 943P, $\sim 5 \times 10^{8}$ gain), where the electron pulses generated from a single photon are counted with a photon-counting card (PMS 400, Becker and Hickl). To prevent saturation, the CPM is turned off by a high voltage switching circuit ("gating box", designed and built in-house) from the time the laser is triggered until $\sim 60 \mathrm{~ns}$ after the laser pulse $(\mathrm{FWHM}=35 \mathrm{~ns})$. The use of a temporal gating allows sensitive measurement of the fluorescence emitted from the electronically excited $\mathrm{OH}$ and discrimination against laser scattered light.

\subsection{Reference cell}

The wavelength of the laser is changed by a stepper motor, which controls the angle of the diffraction grating within the Ti:Sapp laser cavity. The absolute wavelength of the second harmonic of the Ti: Sapp $(\lambda \approx 462 \mathrm{~nm})$ is monitored by a wavemeter (Wavemaster 33-2650, Coherent). However, the resolution of this wavemeter (precision $\pm 0.001 \mathrm{~nm}$, accuracy $\pm 0.005 \mathrm{~nm}$ ) is insufficient to locate the $\mathrm{OH} \mathrm{Q}_{1}(2)$ rotational line $(\lambda=307.995 \mathrm{~nm})$. The reference cell facilitates scanning over and identification of the $\mathrm{Q}_{1}(2)$ peak. With the reference cell maintained at low pressure ( $\sim 3$ Torr), humidified cabin air is passed over an electrically heated 80:20 Ni:Chrome filament, producing $\mathrm{OH}$ radicals by pyrolysis of water vapour (Stevens et al., 1994; Wennberg et al., 1994). The reference cell receives $2-3 \mathrm{~mW}(\sim 4 \%)$ of the total UV radiation. The $\mathrm{OH}$ fluorescence signal is filtered and focussed onto a CPM perpendicular to the laser beam. The resulting signal is recorded using a photon-counting card. Because of the high concentration of $\mathrm{OH}$ radicals produced in the reference cell, discriminating the $\mathrm{OH}$ fluorescence signal from the background laser scatter does not require gating of the CPM.

Figure 3 shows the signal observed in the $\mathrm{OH}, \mathrm{HO}_{2}$ and reference cells during a measurement cycle on a flight on August $8^{\text {th }}, 2006$. The $\mathrm{OH}$ signal in the reference cell is typically $12000 \mathrm{cts} \mathrm{s}^{-1}$ above the laser scatter background of approximately $4000 \mathrm{cts} \mathrm{s}^{-1}$. The first 25 points on the figure show the $\mathrm{OH}$ fluorescence while scanning over the $\mathrm{Q}_{1}$ (2) rotational line of $\mathrm{OH}$ to locate the wavelength of the peak fluorescence (finding line: from $\lambda=307.990 \mathrm{~nm}$ to $\lambda=308.000 \mathrm{~nm}$ ). Points $\sim 25-375$ in $\mathrm{OH}$ and reference cells show the online fluorescence signal (and background) as the laser wavelength is tuned to the peak of fluorescence. In the $\mathrm{HO}_{2}$ cell, no fluorescence signal is observed until the injection of $\mathrm{NO}$ to titrate $\mathrm{HO}_{2}$ to $\mathrm{OH}$ (points 85-375). Points $\sim 375-450$ show the fluorescence as the laser wavelength is tuned to a wavelength which does not induce fluorescence in order to measure the background signal (offline).

The signal in the reference cell varies with aircraft cabin pressure due to changes in the laser wavelength. The variation in the wavelength generated by the laser is due to the changing refractive index of the cabin air with pressure compared with the material of the laser grating. This change in wavelength away from the maximum of the $\mathrm{OH}$ transition results in the signal due to $\mathrm{OH}$ fluorescence varying with cabin pressure. Independent of this laser wavelength change with pressure, fluctuations in cell pressure will also alter the instrument sensitivity. While the effect of changing cell pressure on sensitivity can be determined by calibration, it cannot be decoupled from changes in wavelength during AMMA as the Ti:Sapp laser cavity was not kept at constant pressure, so only data recorded on level flights (with constant laser wavelength) are considered. 


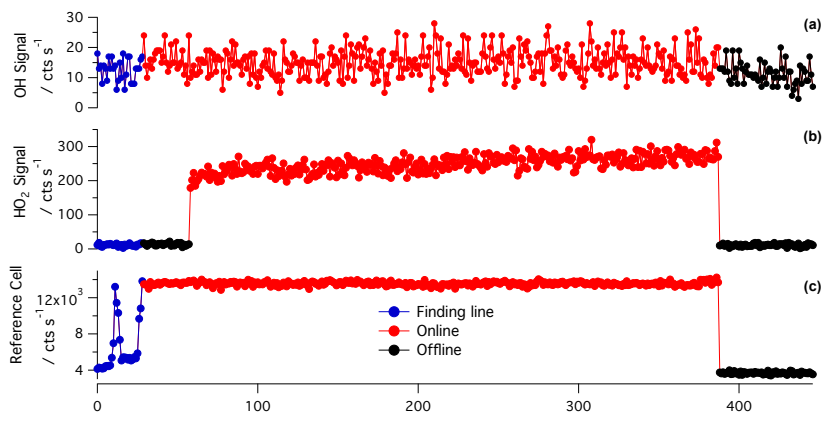

Fig. 3. The raw signal observed in the (a) $\mathrm{OH}\left(\right.$ cts s $^{-1}$ ), (b) $\mathrm{HO}_{2}$ $\left(\right.$ cts $\mathrm{s}^{-1}$ ) and (c) reference cell (cts $\mathrm{s}^{-1}$ ) for a measurement cycle during a flight on 8 August 2006. The $Q_{1}$ (2) rotational line is scanned over ("finding line", points $1-25$, blue). Online (points $\sim 25-375$, red) represents the online measurement period. Offline (points 375-450, black) represents the background signal to be removed in the analysis. A $2.2 \%(1 \sigma)$ variation in reference signal is observed online.

\subsection{Data analysis}

The laser is operated at a pulse repetition frequency of $5 \mathrm{kHz}$ and the contribution of the solar and dark counts (CPM thermal noise) to the observed signal is determined for each laser pulse. The fluorescence signal is collected for $1 \mu \mathrm{s}$ (Gate A). After a $5 \mu$ s delay the non-laser background signal is recorded for $20 \mu \mathrm{s}$ (Gate B) and the signal solely due to $\mathrm{OH}$ fluorescence and laser background, $\mathrm{Sig}_{\mathrm{fl}}$, is calculated:

$\operatorname{Sig}_{\mathrm{fl}}=\operatorname{SigA}-\frac{\operatorname{SigB}}{20}$,

where SigA (cts) is the number of counts in the $1 \mu$ s collection Gate $\mathrm{A}\left(\mathrm{cts} \mathrm{s}^{-1}\right)$ and $\mathrm{SigB}$ is the number of counts in the $20 \mu$ s collection gate (typically 0 or $1 \mathrm{cts} \mathrm{s}^{-1}$ ). The total signal, $\mathrm{Sig}_{\mathrm{fl}}$ (cts), is then recorded at $1 \mathrm{~Hz}$ and normalised for laser power $(\mathrm{P}, \mathrm{mW})$. For $\mathrm{OH}$, the normalised offline signal $\mathrm{OH} \mathrm{Sig}{ }_{\text {offline }}$ is subtracted from the normalised online signal $\mathrm{OH} \mathrm{Sig}_{\text {online, }}$ leaving the signal solely due to $\mathrm{OH}(\mathrm{OH} \mathrm{Sig}$ $\left(\right.$ cts s $\left.{ }^{-1} \mathrm{~mW}^{-1}\right)$ ):

$\mathrm{OH} \mathrm{Sig}=\mathrm{OH} \mathrm{Sig}_{\text {online }}-\mathrm{OH} \mathrm{Sig}$ offline

As shown in Fig. 3, $\mathrm{HO}_{2}$ Sig is the difference in normalised online signal observed with $\mathrm{NO}$ injected $\left(\mathrm{HO}_{2}+\mathrm{OH}\right)$ and without $\mathrm{NO}$ added $(\mathrm{OH}$ only). The concentration of $\mathrm{OH}$ is then calculated using the experimentally determined instrument sensitivity $\left(C_{\mathrm{OH}}\right.$, cts s ${ }^{-1} \mathrm{~mW}^{-1}$ molecule $\left.{ }^{-1} \mathrm{~cm}^{3}\right)$ :

$[\mathrm{OH}]=\frac{\mathrm{OH} \mathrm{Sig}}{C_{\mathrm{OH}}}$

The concentration of $\mathrm{HO}_{2}$ is calculated using the experimentally determined instrument sensitivity $\mathrm{HO}_{2} \quad\left(C_{\mathrm{HO}_{2}}\right.$, cts s$^{-1} \mathrm{~mW}^{-1}$ molecule ${ }^{-1} \mathrm{~cm}^{3}$ ):

$\left[\mathrm{HO}_{2}\right]=\frac{\mathrm{HO}_{2} \mathrm{Sig}}{C_{\mathrm{HO}_{2}}}$

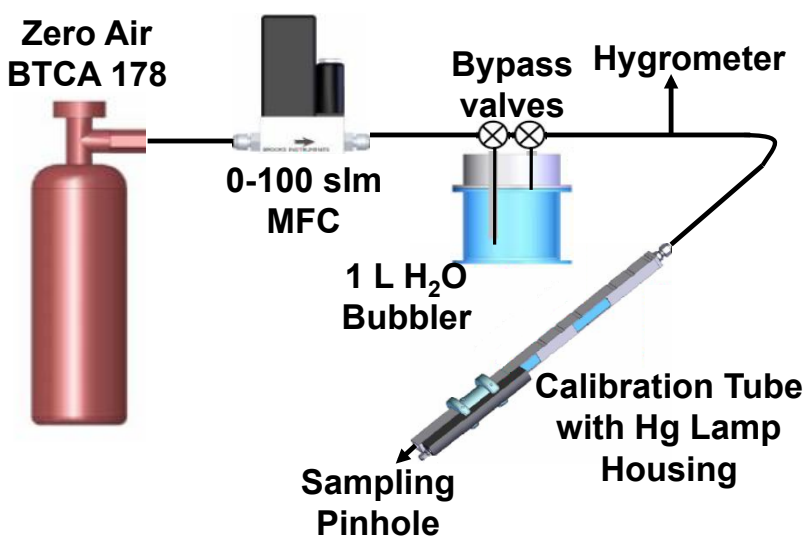

Fig. 4. Schematic representation of the calibration system. Zero air is humidified and passed through the calibration tube, where it is photolysed to produce a known concentration of $\mathrm{OH}$ and $\mathrm{HO}_{2}$.

\subsection{Calibration}

Before and after deployment, the instrument sensitivity was determined over the range of cell pressures experienced during the AMMA campaign (between 1.5 and 2.1 Torr, equivalent to $2-2.8 \mathrm{hPa}$ ) using a method similar to that employed by Faloona et al. (2004) and Martinez et al. (2010). Pinholes with diameters between 0.65 and $0.85 \mathrm{~mm}$ were used to obtain cell pressures between 1.5 and 2.7 Torr $(2-3.6 \mathrm{hPa})$ respectively.

By varying the current supplied to a low-pressure mercury lamp, a range of concentrations of $\mathrm{OH}$ and $\mathrm{HO}_{2}$ were produced from the photolysis of water in humidified air (constant $\left.\left[\mathrm{H}_{2} \mathrm{O}\right]\right)$ at $\lambda=184.9 \mathrm{~nm}$ :

$[\mathrm{OH}]=\left[\mathrm{HO}_{2}\right]=\left[\mathrm{H}_{2} \mathrm{O}\right] \sigma_{\mathrm{H}_{2} \mathrm{O}} \phi_{\mathrm{OH}} F \delta t$

where $\sigma_{\mathrm{H}_{2} \mathrm{O}}$ is the absorption cross-section of water at $\lambda=184.9 \mathrm{~nm} \quad\left(7.14 \pm 0.2 \times 10^{-20}\right.$ molecule ${ }^{-1} \mathrm{~cm}^{2}$; Cantrell et al., 1997a), $\phi_{\mathrm{OH}}$ and $\phi_{\mathrm{HO}_{2}}$ are the photodissociation quantum yields of $\mathrm{OH}$ and $\mathrm{HO}_{2}$ respectively $(=1), F$ is the photon flux of the mercury lamp (photon $\mathrm{cm}^{-2} \mathrm{~s}^{-1}$ ) at $\lambda=184.9 \mathrm{~nm}$ and $\delta t$ is the residence time in the photolysis region.

Figure 4 shows the experimental set-up of the calibration system. A known flow (ca. $50 \mathrm{slm}$ : $\mathrm{L} \mathrm{min}^{-1}$ at standard temperature and pressure) of ultra high-purity air (BTCA 178, BOC Special Gases) is introduced into the system, with a variable fraction of the flow diverted (through bypass valves) to a bubbler containing distilled water in order to humidify the air. After mixing, most of the calibration gas passes through a $30 \mathrm{~cm}$ long black-anodised square $(1.27 \mathrm{~cm} \times 1.27 \mathrm{~cm})$ aluminium tube, where the gas is photolysed by the $\lambda=184.9 \mathrm{~nm}$ emission of a mercury lamp of known actinic flux (see below) to produce equal concentrations of $\mathrm{OH}$ and $\mathrm{HO}_{2}$ before delivery to the FAGE sampling point. Immediately prior to the air entering the calibration tube, a small flow is diverted to a dew-point hygrometer 

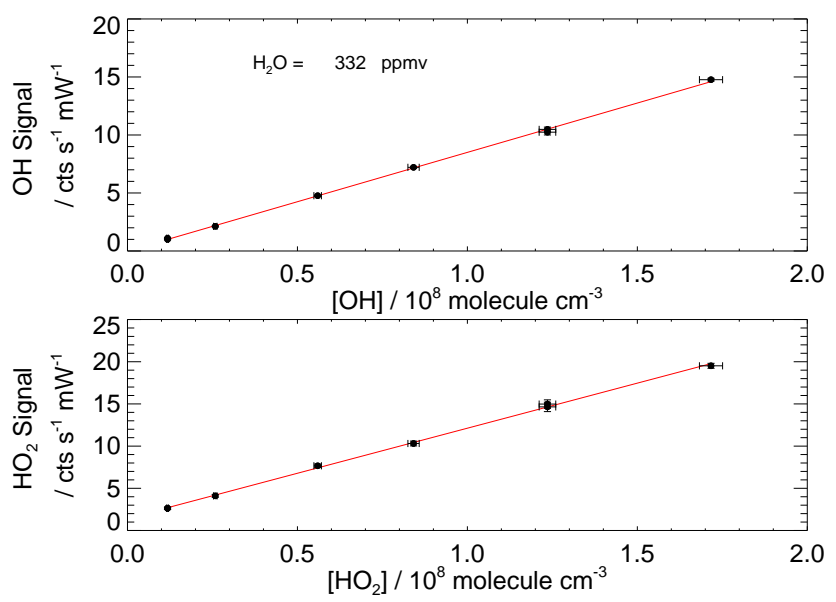

Fig. 5. Multipoint calibration for $\mathrm{OH}$ and $\mathrm{HO}_{2}$ at a constant water vapour (332 ppmv). Calibrations were conducted for a range of water vapour mixing ratios between 10000 ppmv and $332 \mathrm{ppmv}$. The lamp current was varied to produce a range of $\mathrm{OH}$ and $\mathrm{HO}_{2}$ concentrations from $1 \times 10^{7}$ to $1.7 \times 10^{8}$ molecule $\mathrm{cm}^{-3}$. Error bars indicate the standard deviation of the data within each data point.

(CR4, Buck Research Instruments) to measure the concentration of water vapour in the flow. There are three $3.81 \mathrm{~cm}$ Suprasil $^{\circledR}$ windows separated by equal distance down the length of the calibration tube. At high flow rates through the calibration tube, the gas was found to have a uniform velocity profile consistent with turbulent flow. The mercury lamp is housed in a nitrogen-purged aluminium casing, and usually mounted over the window closest to the exit of the calibration tube. This purged housing is heated to maintain a stable lamp temperature $\left( \pm 1^{\circ} \mathrm{C}\right)$, while the nitrogen flow prevents both ozone formation within the housing and absorption of radiation by ambient water vapour and oxygen prior to the light entering the calibration tube. The lamp is collimated using thin walled tubes ( $3 \mathrm{~mm}$ diameter, $8 \mathrm{~mm}$ length) packed together in front of the lamp. These tubes are used to create a more uniform actinic flux in the photolysis region.

Prior to calibration, the lamp flux at $\lambda=184.9 \mathrm{~nm}$ was determined by $\mathrm{N}_{2} \mathrm{O}$ actinometry through the generation of a quantifiable mixing ratio of $\mathrm{NO}$ from the photolysis of $10 \%$ $\mathrm{N}_{2} \mathrm{O}$ in air. The theory and method of this technique has been described extensively in previous publications (e.g. Edwards et al., 2003; Faloona et al., 2004; Glowacki et al., 2007; Whalley et al., 2007). Two corrections were made in the calculation of the flux, $F$. In the $\mathrm{NO}_{\mathrm{x}}$ analyser (Thermo Electro $42 \mathrm{C}$; detection limit/precision $\sim 50 \mathrm{pptv}$ ) used to measure the NO produced, the introduction of high concentrations of $\mathrm{N}_{2} \mathrm{O}$ results in the reporting of artifically low NO mixing ratios. This is due to increased quenching of the electronically excited $\mathrm{NO}_{2}$ fluorescence by $\mathrm{N}_{2} \mathrm{O}$ within the analyser. The effect of this quenching was characterised and the corrected NO mixing ratios were calculated. The second correc-

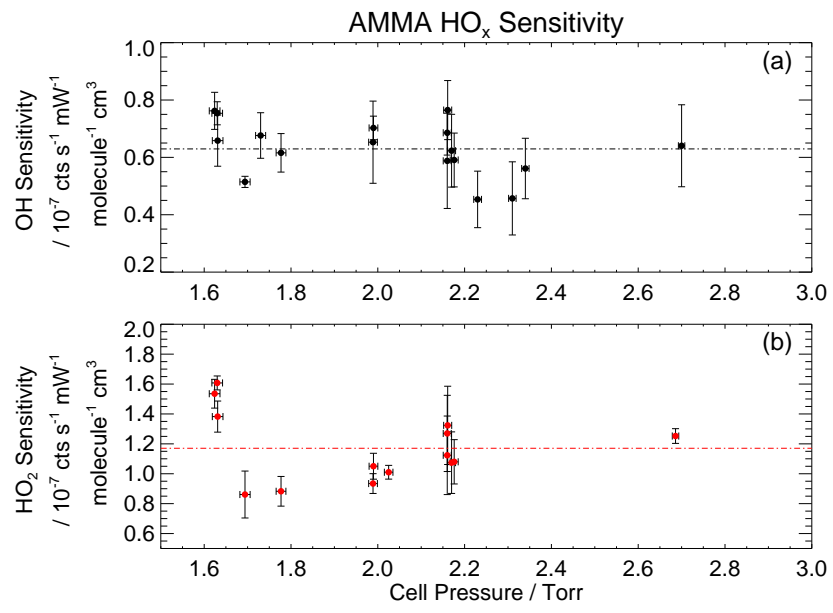

Fig. 6. Instrument Sensitivity as a function of fluorescence cell pressure for $\mathrm{OH}$ (a) and $\mathrm{HO}_{2}$ (b). During AMMA, the cell pressure varied between 1.5 Torr $(9 \mathrm{~km}$ altitude) and 2.1 Torr (sea level). The dashed line indicates the mean sensitivity used for the AMMA dataset $\left(C_{\mathrm{OH}}=0.63\right.$ $( \pm 0.095) \times 10^{-7} \mathrm{cts} \mathrm{s}^{-1} \mathrm{~mW}^{-1}$ molecule ${ }^{-1} \mathrm{~cm}^{3}$ and $C_{\mathrm{HO}_{2}}=1.17$ $( \pm 0.23) \times 10^{-7} \mathrm{cts} \mathrm{s}^{-1} \mathrm{~mW}^{-1}$ molecule $\left.^{-1} \mathrm{~cm}^{3}\right)$.

tion accounted for absorption of the light flux by $\mathrm{N}_{2} \mathrm{O}$ across the width of the photolysis area (Edwards et al., 2003). A linear relationship between the lamp current supplied to the lamp and the flux was observed after corrections, allowing the lamp current to be varied to generate various concentrations of $\mathrm{HO}_{\mathrm{x}}$.

Calibrations were conducted over a range of water vapour mixing ratios from $330 \mathrm{ppmv}$ to $10000 \mathrm{ppmv}$ (parts-permillion, $\left.10^{-6} \mathrm{~mol} \mathrm{~mol}^{-1}\right)$. Figure 5 shows a typical calibration for the lowest water vapour used (332 ppmv). The instrument sensitivity to $\mathrm{OH}$ is a function of water vapour in the gas flow (Smith et al., 2006) due to quenching of electronically excited $\mathrm{OH}$ by the water vapour. Using a constant concentration of water vapour during calibrations ensures a linear relationship between the observed signal and concentration of $\mathrm{OH}$ or $\mathrm{HO}_{2}$.

Over the pressure range observed in the fluorescence cell during AMMA, the sensitivity of the instrument did not vary significantly (Fig. 6) and the mean sensitivities of the instrument to $\mathrm{OH}$ and $\mathrm{HO}_{2}$ were determined $\left(C_{\mathrm{OH}}=0.63( \pm 0.095)\right.$ $\times 10^{-7}$ cts s $^{-1} \mathrm{~mW}^{-1}$ molecule ${ }^{-1} \mathrm{~cm}^{3}$ and $C_{\mathrm{HO}_{2}}=1.17$ $( \pm 0.23) \times 10^{-7} \mathrm{cts} \mathrm{s}^{-1} \mathrm{~mW}^{-1}$ molecule $\left.{ }^{-1} \mathrm{~cm}^{3}\right)$. The calibration coefficients for a given pressure before and after the campaign were found to be within $5 \%$, well within the calculated uncertainty. While in-flight calibrations were not possible during the AMMA campaign, instrumentation to allow calibration during flight is currently being developed. The instrument sensitivity to $\mathrm{OH}$ is half that of $\mathrm{HO}_{2}$ and is due to a higher loss of $\mathrm{OH}$ compared to $\mathrm{HO}_{2}$ on the surface of the cell between sampling and detection. 


\subsection{Limit of detection}

It is possible to calculate the instrumental Limit Of Detection (LOD) for $\mathrm{OH}$ and $\mathrm{HO}_{2}$ by carrying out a t-test between an observed concentration and zero concentration $\left(0\right.$ molecule $\left.\mathrm{cm}^{-3}\right)$, assuming the variance in the background is constant throughout the measurement cycle and is represented by the variance in the offline measurement. For unequal sample sizes (online and offline), the minimum detectable $\mathrm{HO}_{\mathrm{x}}, \mathrm{Sig}_{\min }$, for a given confidence interval can be calculated:

$\operatorname{Sig}_{\min }=T_{\mathrm{CI}} \sqrt{\frac{1}{n}+\frac{1}{m}} \sigma_{\mathrm{bg}}$

where $T_{\mathrm{CI}}$ is the $T$ value for a given confidence interval $\left(T_{69 \%}=1\right), n$ and $m$ are the sample sizes online and offline respectively defined by the sampling frequency and $\sigma_{\mathrm{bg}}$ is the standard deviation of the background, which is assumed to be representative of the standard deviation of the background signal during the online sample. Previous studies have assumed the background signal obeys Poisson statistics (Stevens et al., 1994; Faloona et al., 2004; Martinez et al., 2010) and thus:

$\sigma_{\mathrm{bg}}=\sqrt{\left(S_{\mathrm{lb}}+S_{\mathrm{sb}}+S_{\mathrm{dc}}\right)}$

where $S_{\mathrm{lb}}$ is the signal due to laser scatter, $S_{\mathrm{sb}}$ is the signal due to solar background and $S_{\mathrm{dc}}$ are the dark counts of the CPM.

$\mathrm{Sig}_{\min }$ is converted into a minimum detectable concentration of $\mathrm{OH}$ (and $\mathrm{HO}_{2}$ ) by:

$$
\begin{aligned}
{\left[\mathrm{OH}_{\min }\right] } & =\frac{\mathrm{OH} \mathrm{Sig}_{\text {min }}}{C_{\mathrm{OH} P}} \\
{\left[\mathrm{HO}_{2}\right. \text { min }} & =\frac{\mathrm{HO}_{2} \mathrm{Sig}_{\text {min }}}{C_{\mathrm{HO}_{2} P} P}
\end{aligned}
$$

where $C_{\mathrm{OH}}$ and $C_{\mathrm{HO}_{2}}$ are the instrument sensitivity to $\mathrm{OH}$ and $\mathrm{HO}_{\mathrm{x}}\left(\mathrm{cts} \mathrm{s}^{-1} \mathrm{~mW}^{-1}\right.$ molecule $\mathrm{e}^{-1} \mathrm{~cm}^{3}$ ) respectively and $P$ is the laser power in the cell $(\mathrm{mW})$. Using a confidence interval of $69 \%$ ( $T$ value $=1$ ), a limit of detection is calculated for each measurement cycle $(\sim 5 \mathrm{~min})$.

Table 1 shows the $\mathrm{OH}$ and $\mathrm{HO}_{2}$ LODs calculated for a typical measurement cycle during the the final flight of the AMMA aircraft campaign (August 2006). During the campaign the mean OH LOD was $7.1 \times 10^{5}$ molecule $\mathrm{cm}^{-3}$ and the mean $\mathrm{HO}_{2}$ LOD was $7.5 \times 10^{5}$ molecule $\mathrm{cm}^{-3}$ for a one minute integration time. In order to improve sensitivity to $\mathrm{HO}_{2}$, the time between laser trigger and fluorescence collection is shortened, compared to that set for $\mathrm{OH}$, which increases the background signal (and therefore $\sigma_{\mathrm{bg}}$ ) and hence limit of detection but will also increase the sensitivity to $\mathrm{HO}_{2}$. This shortened delay time is suitable for $\mathrm{HO}_{2}$ observations, as a typical concentration of $\mathrm{HO}_{2}$ in the atmosphere is around two orders of magnitude greater than the calculated LOD.
Table 1. Limit Of Detection (LOD) for a $60 \mathrm{~s}$ integration calculated for a typical run on 17 August 2006.

\begin{tabular}{lll}
\hline Parameter & $\mathrm{OH}$ & $\mathrm{HO}_{2}$ \\
\hline$T_{69 \%}$ & 1 & 1 \\
$P / \mathrm{mW}$ & 10.7 & 5.7 \\
$C_{\mathrm{HO}_{\mathrm{x}}}\left(10^{-7} \mathrm{cts} \mathrm{s}^{-1} \mathrm{~mW}^{-1}\right.$ molecule $\left.^{-1} \mathrm{~cm}^{3}\right)$ & 0.63 & 1.17 \\
$m$ & 60 & 60 \\
$n$ & 60 & 60 \\
$\sigma_{\mathrm{bg}} / \mathrm{cts} \mathrm{s}$ & 8.1 & 33.9 \\
{$\left[\mathrm{HO}_{\mathrm{x}}\right]_{\min }\left(10^{6}\right.$ molecule $\left.\mathrm{cm}^{-3}\right)$} & 0.8 & 1.6 \\
\hline
\end{tabular}

During AMMA, the performance of the YAG laser was degraded during flight due to an increase in cabin temperature, which often increased from $15^{\circ} \mathrm{C}$ to $35^{\circ} \mathrm{C}$ during a flight. The reduced power output from the YAG resulted in the Ti:Sapphire laser taking longer to reach the lasing threshold. The time delay between the laser trigger and the laser pulse was found to increase by several tens of ns during a given flight, an increase large enough to increase the laser background signal and affect both the sensitivity of the instrument to $\mathrm{HO}_{\mathrm{x}}$ and the instrumental limit of detection. As the background is recorded at the end of the measurement cycle, it is possible that an increase in background signal throughout a measurement cycle could also lead to a slight underestimation of the $\mathrm{OH}$ concentration.

Since the AMMA campaign, a diagnostic system coupling a fast photodiode (Hamamatsu, S6468) to an oscilloscope (Waverunner LT372, Le Croy) has been developed to monitor the timing of the CPM gate trigger relative to the laser pulse and not the laser trigger. This technique allows the time between the laser pulse itself and the CPM gate trigger to be adjusted automatically in flight every $10 \mathrm{~s}$, thus maintaining a constant time delay. A similar system is now used in the Leeds ground-based FAGE instrument and is described in detail in Whalley et al. (2009). Using this system, the sensitivity of the instrument to the time interval between the laser pulse and the fluorescence collection was investigated. Figure 7 shows how the background signal increases dramatically as the time between the laser pulse and fluorescence collection decreases and more of the laser pulse is detected. The limit of detection is also shown to worsen with at shorter time intervals (Fig. 7).

Under normal operating conditions (delay of $60 \mathrm{~ns}$ ), the instrumental LOD for $\mathrm{OH}\left(\sim 7 \times 10^{5}\right.$ molecule $\left.\mathrm{cm}^{-3}\right)$ is below peak concentrations of $\mathrm{OH}$ observed in the tropics (e.g. $[\mathrm{OH}]=9 \times 10^{6}$ molecule $\mathrm{cm}^{-3}$ observed at a tropical marine site in summer, Whalley et al., 2009). However, as the delay time decreases, the LOD becomes comparable to ambient concentrations of $\mathrm{OH}$. Ambient concentrations of $\mathrm{HO}_{2}$ are much greater than the $\mathrm{HO}_{2} \mathrm{LOD}$ (e.g. $\left[\mathrm{HO}_{2}\right]=6 \times 10^{8}$ molecule $\mathrm{cm}^{-3}$, Whalley et al., 2009) 


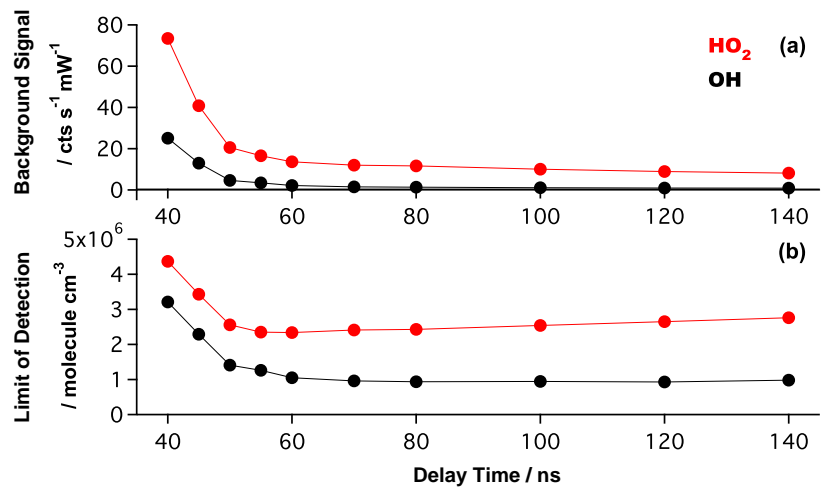

Fig. 7. Typical instrument performance for $\mathrm{OH}$ (black) and $\mathrm{HO}_{2}$ (red) changes with the time interval between laser trigger and fluorescence collection. (a) Background signal (cts s ${ }^{-1} \mathrm{~mW}^{-1}$ ) and (b) Limit of Detection (molecule $\mathrm{cm}^{-3}$ ).

and the relative increase of $\mathrm{HO}_{2} \mathrm{LOD}$ compared to ambient concentrations has far less of an impact than for $\mathrm{OH}$.

\subsection{Instrumental uncertainty}

During AMMA, water vapour ranged from $300 \mathrm{ppmv}$ at altitudes above $4 \mathrm{~km}$ to almost 30000 ppmv on occasion in the boundary layer. In the laboratory during ground calibrations, the impact of humidity on the calibration coefficient of the aircraft FAGE instrument was determined. For water vapour mixing ratios between $500 \mathrm{ppmv}$ and $10000 \mathrm{ppmv}$, changes of $11 \%$ and $9 \%$ were observed for $C_{\mathrm{OH}}$ and $C_{\mathrm{HO}_{2}}$ respectively. Although the mixing ratio of water vapour was observed on occasion to be higher than this during AMMA, calibrations of other configurations of FAGE instruments up to 20000 ppmv in Leeds have not observed a significant further change in the calibration sensitivity beyond 10000 ppmv.

The influence of temperature on the calibration coefficient has not been systematically characterised. However, the distance between the sampling pinhole and the fluorescence cell inside the aircraft $(50 \mathrm{~cm}$ for the $\mathrm{OH}$ cell) should allow sufficient time for enough collisions to ensure equilibration to the temperature within the aircraft. In an earlier configuration of a ground-based FAGE instrument (similar nozzle diameter), the rotational temperature of the hydroxyl radical was measured as a function of distance between the sampling pinhole and the laser-excitation axis (Creasey et al., 1997). Following substantial cooling due to expansion within a supersonic jet, the temperature rose to close to ambient at the Mach Disk, followed by a slight cooling before reaching ambient again at $\sim 20 \mathrm{~cm}$. The first fluorescence cell $(\mathrm{OH})$ is $50 \mathrm{~cm}$ from the inlet, and a thermocouple placed in the gas flow between the $\mathrm{OH}$ and $\mathrm{HO}_{2}$ fluorescence cells observed room temperature when the instrument was sampling laboratory air. Therefore, it is expected that the temperature within the fluorescence cells will have reached a temperature close to that within the aircraft, although this has not been explicitly verified.
The instrumental uncertainty is calculated as the rootmean-square of the uncertainty in the determination of the flux (13\% and includes $\mathrm{N}_{2} \mathrm{O}$ calibration, rate constants, lamp current, etc.), the hygrometer (1\%), absorption cross-section of $\mathrm{H}_{2} \mathrm{O}(2.8 \%)$, flow controller error $(1 \%)$, excitation peak location (5\%), laser power reading (3\%), the fit to the multipoint calibration ( $9 \%$ for $\mathrm{OH}$ and $6 \%$ for $\mathrm{HO}_{2}$ ), the standard error in the fit in Fig. 5 (15\% for $\mathrm{OH}$ and $20 \%$ for $\mathrm{HO}_{2}$ ) and the uncertainty due to effects of humidity $(12 \%$ for $\mathrm{OH}$ and $9 \%$ for $\mathrm{HO}_{2}$ ), leading to an overall uncertainty of $25 \%$ for $\mathrm{OH}$ and $26 \%$ for $\mathrm{HO}_{2}$.

\subsection{Ancillary measurements}

$J\left(\mathrm{O}^{1} \mathrm{D}\right)$ data was provided by the University of Leicester. $J\left(\mathrm{O}^{1} \mathrm{D}\right)$ is the combination of the upward and downward welling observations. During the campaign the downward pointing $J\left(\mathrm{O}^{1} \mathrm{D}\right)$ actinometer failed and subsequent observations were scaled to the combined $J\left(\mathrm{NO}_{2}\right)$ observations, as described in Stone et al. (2010). Core aircraft data such as temperature, pressure, $\mathrm{CO}$ (Aerolaser AL5002 instrument), $\mathrm{O}_{3}$ (TECO 49UV photometery instrument) and liquid water content (Johnson Williams Liquid Water Content probe) were provided by the Facility of Airborne Atmospheric Measurements (FAAM) (Reeves et al., 2010), PAN data were provided by the University of York (Stewart et al., 2008) and $\mathrm{NO}_{\mathrm{x}}, \mathrm{NO}_{\mathrm{y}}$ (Stewart et al., 2008), acetonitrile and isoprene (Proton Transfer Mass Spectrometry - PTr-MS; Murphy et al., 2010) were provided by the University of East Anglia.

\section{Results: observations of $\mathrm{OH}$ and $\mathrm{HO}_{2}$ radicals}

The Leeds aircraft FAGE instrument observed $\mathrm{OH}$ and $\mathrm{HO}_{2}$ over a range of altitudes $(500 \mathrm{~m}-9 \mathrm{~km})$ and through various airmasses over West Africa. The observed signal was processed and the concentration of $\mathrm{OH}$ and $\mathrm{HO}_{2}$ calculated using the instrument sensitivity determined by calibration, as described in Sect. 2.6. The $1 \mathrm{~Hz}$ mixing ratios of $\mathrm{OH}$ and $\mathrm{HO}_{2}$ were calculated using the temperature and pressure recorded on the aircraft and averaged over $60 \mathrm{~s}$. The $1 \mathrm{~Hz}$ $\mathrm{HO}_{2}$ data were used directly in the study of $\mathrm{HO}_{2}$ in clouds (Sect. 4.1).

$\mathrm{HO}_{\mathrm{x}}$ observations were made on 13 flights during July and August 2006, with flights both during day and at night. Figure 8 shows the spatial distribution of $\mathrm{HO}_{2}$ observed over West Africa during the AMMA campaign. The aircraft was based in Niamey, Niger and $\mathrm{HO}_{\mathrm{x}}$ observations were made over barren soil in the north (Sahel region of northern Niger and Mali), over regions of forest (Benin) and out over the Gulf of Guinea to the south. An overview of the aircraft measurements can be found in Reeves et al. (2010) and an overview of the range of $\mathrm{HO}_{\mathrm{X}}$ observations observed on various flights is shown in Table 2. 
Table 2. Overview of HOx observations during AMMA flights. Flights were conducted at various times of day and over a range of terrain from Sahel to the north to heavily forested regions to the south, as well as over the Gulf of Guinea to the far south

\begin{tabular}{lllll}
\hline Date & Flight No. & Time (LT) & Location/Conditions & $\mathrm{HO}_{\mathrm{X}}$ Data Range \\
\hline $21 / 07 / 2006$ & B217 & $14: 30-18: 30$ & Sahel/Soil Moisture & $\mathrm{HO}_{2}=5-25$ pptv \\
$22 / 07 / 2006$ & B218 & $15: 30-18: 00$ & Convective outflow & $\mathrm{HO}_{2}=2-20 \mathrm{pptv}$ \\
$25 / 07 / 2006$ & B219A & $13: 00-16: 00$ & Forest: Afternoon & $\mathrm{OH}=0-0.6 \mathrm{pptv}$ \\
$25 / 07 / 2006$ & B219B & $18: 30-22: 00$ & Forest: Night & $\mathrm{HO}_{2}=0-8 \mathrm{pptv}$ \\
$27 / 07 / 2006$ & B220 & $12: 00-14: 00$ & Forest: Noon & $\mathrm{HO}_{2}=5-40$ pptv \\
$06 / 08 / 2006$ & B227 & $14: 00-17: 00$ & Sahel & $\mathrm{OH}=0-0.4$ pptv; $\mathrm{HO}_{2}=5-14$ pptv \\
$08 / 08 / 2006$ & B228 & $09: 00-14: 30$ & Ocean/coastal & $\mathrm{OH}=0-0.7$ pptv; $\mathrm{HO}_{2}=0-30$ pptv \\
$08 / 08 / 2006$ & B229 & $15: 00-17: 30$ & Lagos & $\mathrm{OH}=0-0.5$ pptv; $\mathrm{HO}_{2}=5-20$ pptv \\
$14 / 08 / 2006$ & B232 & $05: 00-08: 00$ & Forest: Dawn & $\mathrm{HO}_{2}=0-5$ pptv \\
$15 / 08 / 2006$ & B233 & $05: 00-09: 00$ & Forest: Dawn & $\mathrm{HO}_{2}=0-18$ pptv \\
$16 / 08 / 2006$ & B234 & $14: 30-18: 00$ & Aircraft Intercomparison & $\mathrm{HO}_{2}=2-23$ pptv \\
$17 / 08 / 2006$ & B235A & $11: 00-15: 00$ & Forest: Noon & $\mathrm{OH}_{0} 0-0.7 \mathrm{pptv} ; \mathrm{HO}_{2}=10-42$ pptv \\
$17 / 08 / 2006$ & B235B & $18: 30-21: 00$ & Forest: Night & $\mathrm{HO}_{2}=0.8-2.5$ pptv \\
\hline
\end{tabular}

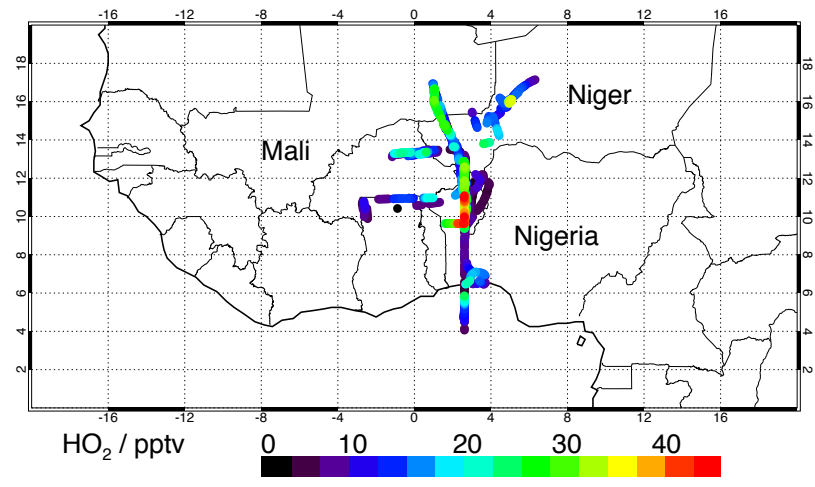

Fig. 8. Spatial distribution of $\mathrm{HO}_{2}$ observed over West Africa during the African Monsoon Multidisciplinary Analyses (AMMA) campaign. Redder colours indicate the highest concentrations of $\mathrm{HO}_{2}$, which were observed over the forested regions of Benin.

Figure 9 is an example of a typical $\mathrm{OH}$ and $\mathrm{HO}_{2}$ time series for a flight on 17 August 2006. The aircraft sampled between $500 \mathrm{~m}$ and $6 \mathrm{~km}$ over the forested region to the north of Benin $\left(7^{\circ}-13^{\circ} \mathrm{N}\right)$. The $\mathrm{O}_{3}$ mixing ratios were found to increase with altitude from $20 \mathrm{ppbv}$ (parts-per-billion, $10^{-9} \mathrm{~mol} \mathrm{~mol}^{-1}$ ) in the boundary layer to over $60 \mathrm{ppbv}$ above $6 \mathrm{~km}$. OH mixing ratios ranged from below the limit of detection to 0.6 pptv. $\mathrm{HO}_{2}$ mixing ratios were found to be more variable from $5 \mathrm{pptv}$ to $50 \mathrm{pptv}$ on a $10 \mathrm{~s}$ time scale. The highest mixing ratio of both $\mathrm{OH}$ and $\mathrm{HO}_{2}$ was observed at $4 \mathrm{~km}$ over the forested region. At the level run at $1.5 \mathrm{~km}$, light cloud was encountered and $\mathrm{HO}_{2}$ mixing ratios were found to rapidly decrease. This effect will be studied in more detail in Sect. 4.1.

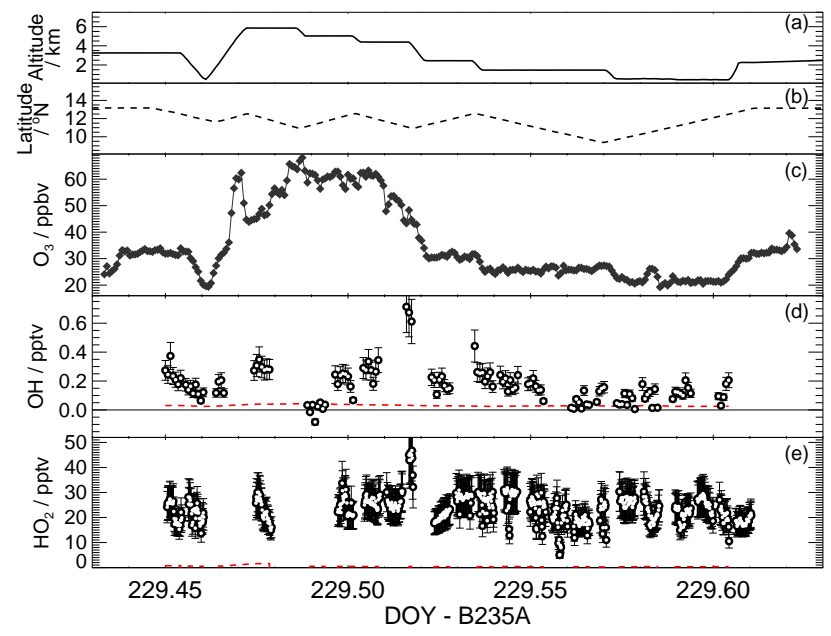

Fig. 9. Time Series of an afternoon flight from 10:40 to 15:00 UTC over the forest region in the north of Benin showing (a) altitude $(\mathrm{km})$, (b) latitude $\left({ }^{\circ} \mathrm{N}\right),(\mathbf{c}) \mathrm{O}_{3}$ (ppbv), (d) OH (pptv, 60 s resolution) and limit of detection (pptv, red dashed line, $60 \mathrm{~s}$ resolution) and (e) $\mathrm{HO}_{2}$ (pptv, $10 \mathrm{~s}$ resolution) and limit of detection (pptv, red dashed line, $10 \mathrm{~s}$ resolution). Error bars on $\mathrm{OH}$ and $\mathrm{HO}_{2}$ indicate the instrumental uncertainty.

Overall during the campaign, the mixing ratios of $\mathrm{OH}$ and $\mathrm{HO}_{2}$ were variable. Figure 10 shows the probability density function of the complete dataset of $\mathrm{OH}$ and $\mathrm{HO}_{2}$ mixing ratios, with the median of the limit of detection. $\mathrm{OH}$ mixing ratios (Fig. 10a) from -0.27 pptv to 1.34 pptv were observed (but with very few points above $1 \mathrm{pptv}$ ), with a median mixing ratio of $0.17 \mathrm{pptv}$. The most frequent $\mathrm{OH}$ mixing ratio was observed at 0.15 pptv. $\mathrm{HO}_{2}$ mixing ratios (Fig. 10b) varied from $-0.32 \mathrm{pptv}$ to $42.65 \mathrm{pptv}$, with a median mixing ratio of 7.97 pptv. 1.5 pptv was the most frequent $\mathrm{HO}_{2}$ mixing 

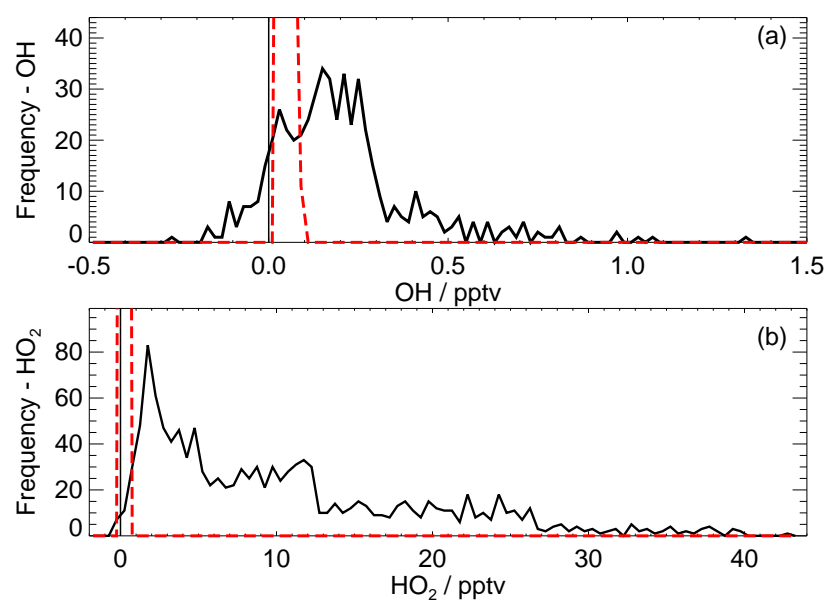

Fig. 10. Probability Density Function (PDF) of 60 s averaged observations (solid black lines): (a) $\mathrm{OH}$, bin size of 0.02 pptv (b) $\mathrm{HO}_{2}$, bin size of 0.5 pptv. PDF of limits of detection (red dashed lines).

ratio observed. For significant periods, the $\mathrm{OH}$ observations were close to the limit of detection of the instrument. This was due to problems with the instability of the timing of the fluorescence detection (as discussed in Sect. 2.7). However, as most $\mathrm{HO}_{2}$ is well above the limit of detection, conclusions can be drawn with more confidence.

\subsection{Diurnal variation}

Although complex mechanisms determine the in situ concentrations of $\mathrm{OH}$ and $\mathrm{HO}_{2}$, daytime $\mathrm{OH}$ production is generally dominated by the photolysis of ozone and the subsequent reaction of $\mathrm{O}\left({ }^{1} \mathrm{D}\right)$ with water and often exhibits a strong diurnal profile (Rohrer and Berresheim, 2006). Figure 11 shows the diurnal profile of the entire dataset of $\mathrm{OH}$ and $\mathrm{HO}_{2}$ radicals as a function of local solar time. Both $\mathrm{OH}$ and $\mathrm{HO}_{2}$ were highly variable throughout the day, with the maximum OH mixing ratio $(\sim 1 \mathrm{pptv})$ coinciding with solar noon, while maximum $\mathrm{HO}_{2}$ mixing ratio ( $\sim 40 \mathrm{pptv}$ ) occurred shortly after solar noon. Mixing ratios of $\mathrm{HO}_{2}$ up to $9 \mathrm{pptv}$ with a mean of 3 pptv were observed at night. The observations of $\mathrm{HO}_{2}$ at night will be discussed in detail in Sect. 4.2.

\section{2 $\mathrm{HO}_{\mathrm{x}}$ observations as a function of altitude}

Figure 12 shows the daytime altitude profiles of (a) $\mathrm{OH}$, (b) $\mathrm{HO}_{2}$ and (c) the $\mathrm{HO}_{2} / \mathrm{OH}$ ratio for data between 09:00 and 15:00 LT (Local Time), with the median value for a given $500 \mathrm{~m}$ altitude bin also shown.

$\mathrm{OH}$ mixing ratios (binned for $500 \mathrm{~m}$ altitude bins up to $6 \mathrm{~km}$ ) are highly variable but the median $\mathrm{OH}$ is relatively constant with altitude at about $0.2 \mathrm{pptv}$, except for a large increase at the top of the boundary layer at $2 \mathrm{~km}$ to $0.7 \mathrm{pptv}$ and distinct decrease at $5 \mathrm{~km}$ to less than $0.05 \mathrm{pptv}$. These observations of $\mathrm{OH}$ fall within the range of previous $\mathrm{OH}$ mea-

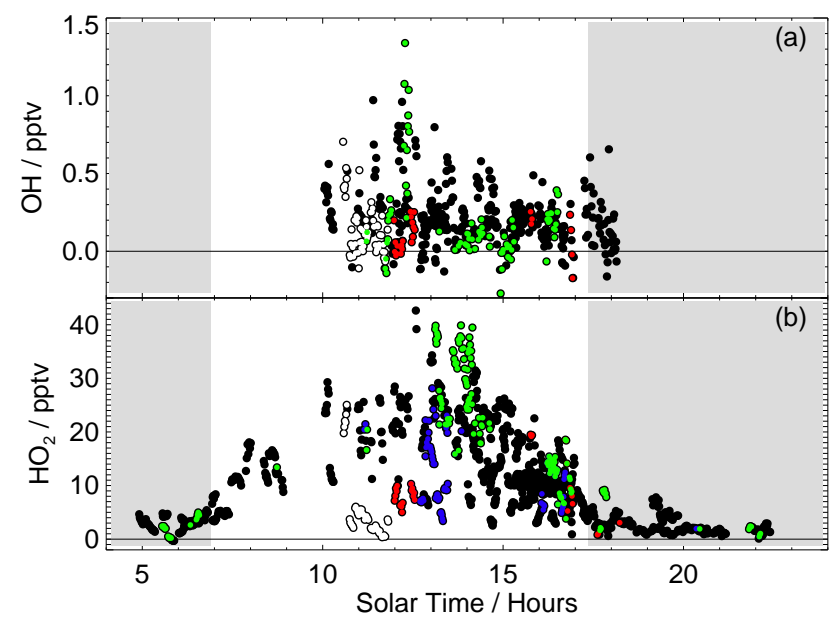

Fig. 11. Diurnal variation of (a) $\mathrm{OH}$ (pptv) and (b) $\mathrm{HO}_{2}$ (pptv). Shaded areas indicate night. Specific data discussed in the text is highlighted: green points indicate high isoprene, red points are data identified as biomass burning, blue points indicate cloud sampling, white points highlight data high altitude data collected on flight B228.

surements. Observations over the mid-latitude and tropical Pacific Ocean found that median $\mathrm{OH}$ was relatively constant with altitude at $\sim 0.1-0.2 \mathrm{pptv}$, increasing from $\sim 0.1 \mathrm{pptv}$ below $2 \mathrm{~km}$ to $\sim 0.2 \mathrm{pptv}$ at $7 \mathrm{~km}$ (INTEX-B and PEM-TropicsB campaigns, Mao et al., 2009; Tan et al., 2001, respectively). Over continental mid-latitudes, median $\mathrm{OH}$ was again relatively constant at all altitudes but at a slightly higher mixing ratio at $\sim 0.2-0.3$ pptv (INTEX-A campaign, Ren et al., 2008). However, boundary layer $\mathrm{OH}$ mixing ratios varied significantly from $0.01-0.6 \mathrm{pptv}$. Observations over a tropical forested region (GABRIEL campaign, Martinez et al., 2010) found much higher $\mathrm{OH}$ mixing ratios with median $\mathrm{OH}$ increasing from $\sim 0.4 \mathrm{pptv}$ in the boundary layer, peaking at $0.75 \mathrm{pptv}$ at $3-4 \mathrm{~km}$ and dropping to $\sim 0.25 \mathrm{pptv}$ at $8 \mathrm{~km}$.

$\mathrm{HO}_{2}$ mixing ratios were also variable at all altitudes and median $\mathrm{HO}_{2}$ varied between 5 and $30 \mathrm{pptv}$ for $500 \mathrm{~m}$ altitude bins up to $7 \mathrm{~km}$. The lowest observed mixing ratios of $\mathrm{HO}_{2}$ were found within $500 \mathrm{~m}$ of the forest surface, but the highest $\mathrm{HO}_{2}$ mixing ratios were observed between $500 \mathrm{~m}$ and $1 \mathrm{~km}$ above the forest. At altitudes above $6 \mathrm{~km}$, individual $\mathrm{HO}_{2}$ data points varied from below the limit of detection to over $30 \mathrm{pptv} \mathrm{HO}_{2}$, with a median value of $\sim 5$ pptv. Previous observations of $\mathrm{HO}_{2}$ generally show a decrease with altitude in all locations. Over the mid-latitude North Pacific $\mathrm{HO}_{2}$ steadily decreased from $\sim 20 \mathrm{pptv}$ at $2 \mathrm{~km}$ to $\sim 7$ pptv at $10 \mathrm{~km}$ (INTEX-B campaign, Mao et al., 2009), while over continental mid-latitudes, median $\mathrm{HO}_{2}$ steadily decreased from $\sim 30$ pptv near the surface (ranging from $\sim 2-$ $60 \mathrm{pptv}$ ) to $\sim 10 \mathrm{pptv}$ at $10 \mathrm{~km}$ (INTEX-A campaign, Ren et al., 2008) and over tropical rainforests median $\mathrm{HO}_{2}$ was 


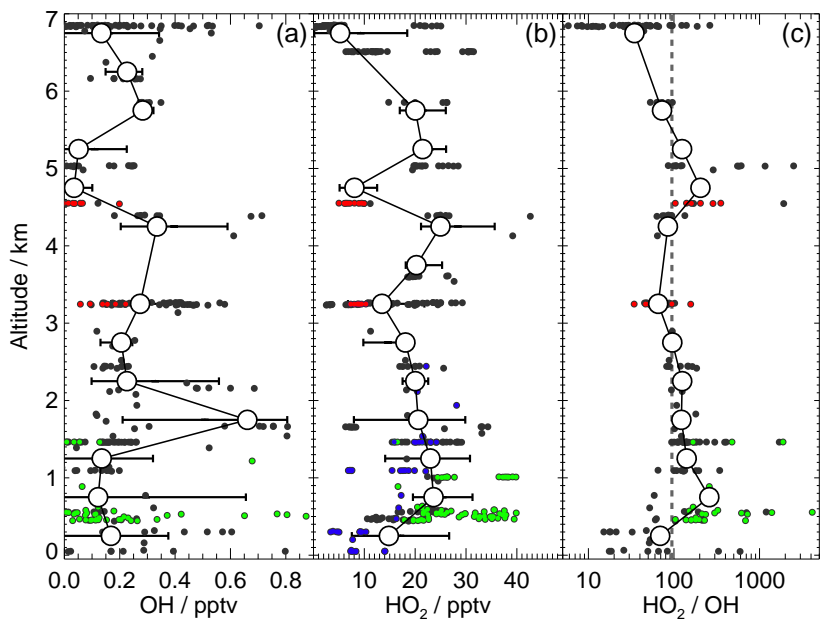

Fig. 12. Median altitude profile of (a) $\mathrm{OH}$ (pptv, black), (b) $\mathrm{HO}_{2}$ (pptv, black) and (c) $\mathrm{HO}_{2} / \mathrm{OH}$ ratio for data between 09:00 and 15:00 UTC. Median values in $500 \mathrm{~m}$ altitude bins are shown as large joined circles, with error bars indicating one standard deviation from the mean. The median $\mathrm{HO}_{2} / \mathrm{OH}$ ratio of 95 is shown as a grey dashed line. $60 \mathrm{~s}$ data are shown as small black dots, with specific data discussed in the text highlighted: Green points indicate high isoprene, red points are data identified as biomass burning, blue points indicate cloud sampling, white points highlight data high altitude data collected on flight B228.

found to decrease from $\sim 40 \mathrm{pptv}$ in the boundary layer to $\sim 10 \mathrm{pptv}$ at $8 \mathrm{~km}$ (GABRIEL campaign, Martinez et al., 2010). However, observations over the tropical south Pacific Ocean show a slightly different profile; $\mathrm{HO}_{2}$ increased from $\sim 10 \mathrm{pptv}$ at the surface to $\sim 20 \mathrm{pptv}$ at $3 \mathrm{~km}$ before steadily decreasing again with altitude to $\sim 5 \mathrm{pptv}$ at $11 \mathrm{~km}$ (PEMTropics-B campaign, Tan et al., 2001).

The $\mathrm{HO}_{2} / \mathrm{OH}$ ratio was highly variable at all altitudes, ranging from 5 to 5000 with a median value of 95 . While $\mathrm{HO}_{x}$ production is dominated by $\mathrm{O}_{3}$ photolysis, the cycling between $\mathrm{OH}$ and $\mathrm{HO}_{2}$ is closely related to the abundance of $\mathrm{CO}$ and NO present (Ehhalt, 1999). At the altitudes considered here, overall $\mathrm{O}_{3}$ varied between $10 \mathrm{ppbv}$ and $100 \mathrm{ppbv}$ and median values gradually increased with altitude to $7 \mathrm{~km}$. $\mathrm{CO}$ varied between $50 \mathrm{ppbv}$ and $450 \mathrm{ppbv}$, but overall decreased slightly with altitude (Reeves et al., 2010). Median NO varied from 100 pptv in the boundary layer to 10 pptv up to $5 \mathrm{~km}$, while total $\mathrm{NO}_{\mathrm{x}}$ was relatively constant with altitude between 100 pptv and 300 pptv (Stewart et al., 2008).

\subsection{Steady state calculations}

As discussed earlier, the photolysis of ozone in the presence of water vapour is the main production pathway of $\mathrm{OH}$ in the unpolluted troposphere (Eq. 1). Figure 13 shows the correlation between $\mathrm{OH}$ and $P(\mathrm{OH})$. $\mathrm{OH}$ mixing ratios were highly variable with only $\sim 11 \%$ of this variability explained by the variability in $P(\mathrm{OH})$. In contrast to this work, previ-

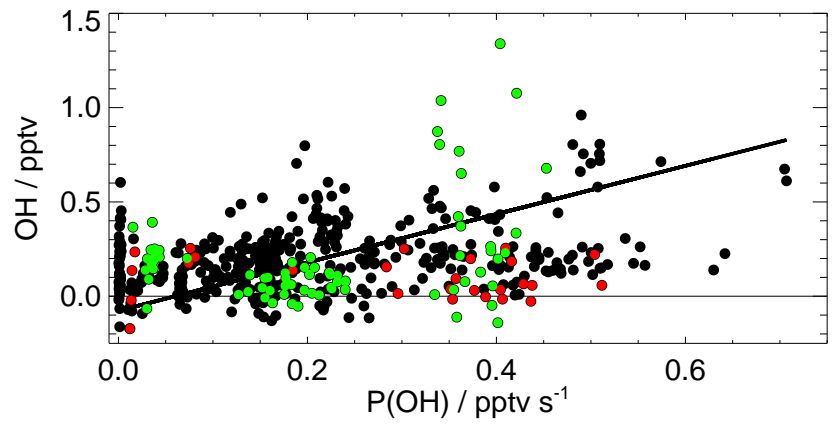

Fig. 13. Correlation between $\mathrm{OH}(\mathrm{pptv})$ and $P(\mathrm{OH})\left(\mathrm{pptv} \mathrm{s}^{-1}\right)$ : slope $=1.28( \pm 0.06) \mathrm{s}$; intercept $=-0.1( \pm 0.01) ; R^{2}=0.11$. Green points indicate observations in the boundary layer with isoprene greater than 300 pptv. Red points indicate observations within a biomass burning plume with acetonitrile higher than $250 \mathrm{pptv}$.

ous observations at ground sites with relatively constant $\mathrm{OH}$ sinks, found that the observed variation in $\mathrm{OH}$ was largely explained by corresponding variations in $P(\mathrm{OH})$ (Rohrer and Berresheim, 2006).

In a clean airmass, the production of $\mathrm{HO}_{2}$ is closely linked to $P(\mathrm{OH})$ and the loss is dominated by the $\mathrm{HO}_{2}$ self reaction:

$\mathrm{HO}_{2}+\mathrm{HO}_{2} \longrightarrow \mathrm{H}_{2} \mathrm{O}_{2}+\mathrm{O}_{2}$

Assuming this production of $\mathrm{HO}_{2}(\sim P(\mathrm{OH}))$ and loss of $\mathrm{HO}_{2}$ through self-reaction (Reaction R7) are equal, a steady state concentration, $\mathrm{HO}_{2}$ ss, can be calculated:

$\mathrm{HO}_{2 \mathrm{ss}}=\sqrt{\frac{P(\mathrm{OH})}{2 k_{R 7}}}=\sqrt{\frac{2 J\left(\mathrm{O}^{1} \mathrm{D}\right)\left[\mathrm{O}_{3}\right] F_{\mathrm{OH}}}{2 k_{\mathrm{HO}_{2}}+\mathrm{HO}_{2}}}$

Figure 14 shows that $\mathrm{HO}_{2}$ ss reproduces $33 \%$ of the variability in the observed $\mathrm{HO}_{2}$ and the slope of $0.62 \pm 0.02$ indicates that overall $\mathrm{HO}_{2}$ ss is overestimating $\mathrm{HO}_{2}$, suggesting missing sinks of $\mathrm{HO}_{2}$. This is not unexpected, given that the rapid loss of $\mathrm{HO}_{2}$ by reaction with species such as $\mathrm{RO}_{2}$ or $\mathrm{NO}_{2}$ or other sinks of $\mathrm{HO}_{\mathrm{x}}$ radicals such as heterogeneous chemistry. From Fig. 14, a number of distinct groups have been identified. $\mathrm{HO}_{2}$ is generally reproduced by $\mathrm{HO}_{2}$ ss in areas of high mixing ratios of isoprene (green) (Sect. 4.3). However, the $\mathrm{HO}_{2} / \mathrm{HO}_{2}$ ss ratio is much less for observations in a biomass burning plume, suggesting the presence of significant $\mathrm{HO}_{2}$ sinks (Sect. 4.4). Stone et al. (2010) describe how the observed photolysis rates were generally slightly lower than the clear sky $J\left(\mathrm{O}^{1} \mathrm{D}\right)$ calculated from the Tropospheric Ultraviolet and Visible (TUV) Radiation model. However, on part of one particular flight (B228, shown in white in Fig. 14) the observations exceeded the calculated $J\left(\mathrm{O}^{1} \mathrm{D}\right)$ by a factor of 1.5. Thus, it is possible that the $P(\mathrm{OH})$ calculated at this time is significantly overestimated.

This simple analysis is suitable for the examination of the overall $\mathrm{HO}_{\mathrm{x}}$ behaviour but detailed interpretation requires a 


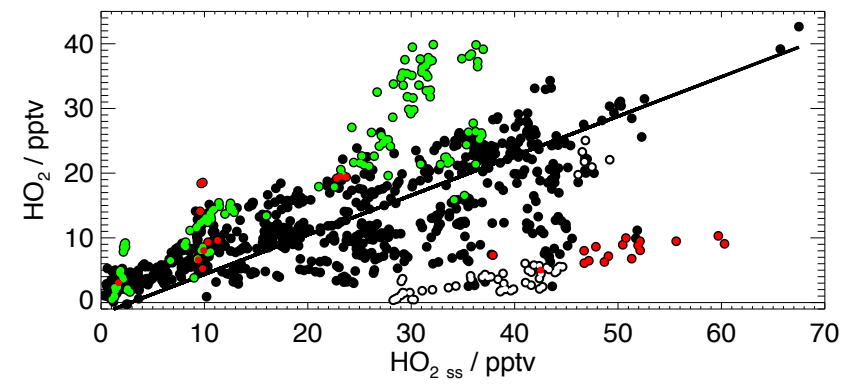

Fig. 14. Correlation between $\mathrm{HO}_{2}$ (pptv) and $\mathrm{HO}_{2}$ ss (pptv): slope $=0.62( \pm 0.02)$; intercept $=-1.75( \pm 0.44) ; R^{2}=0.33$. Green points indicate observations in the boundary layer with isoprene greater than $300 \mathrm{pptv}$. Red points indicate observations within a biomass burning plume with acetonitrile higher than $250 \mathrm{pptv}$. Open circles indicate observations during Flight 228 , when $J\left(\mathrm{O}^{1} \mathrm{D}\right)$ was significantly greater than expected. Each case is discussed in the text.

more comprehensive chemical modelling study. The detailed chemical model employed by Stone et al. (2010) was found to reproduce $55 \%$ of the variability in the observed $\mathrm{HO}_{2}$, compared to $33 \%$ for the study here. However, the chemical model relies on the availability of ancillary data (e.g. NO) so less data points were available for comparison than used in the steady state calculation of $\mathrm{HO}_{\mathrm{X}}$ used in this study. Due to large uncertainties and lack of coverage in the observations of $\mathrm{OH}$ and other key species (e.g. NO, photolysis rates), Stone et al. (2010) could not confidently compare the model to $\mathrm{OH}$.

\section{Discussion}

A number of case studies have been identified in Sect. 3 and will now be examined in detail. A reduction in $\mathrm{HO}_{2}$ was observed when sampling in cloud (Sect. 4.1) and $\mathrm{HO}_{2}$ was observed at night (Sect. 4.2). Compared with $P(\mathrm{OH})$ and $\mathrm{HO}_{2}$ ss, both $\mathrm{OH}$ and $\mathrm{HO}_{2}$ are enhanced in the presence of high isoprene (Sect. 4.3), but are depleted within a biomass burning plume (with acetonitrile higher than 250 pptv) (Sect. 4.4).

\section{1 $\mathrm{HO}_{2}$ in cloud}

When sampling in and around clouds, $\mathrm{HO}_{2}$ was found to rapidly decrease for short episodes, before returning to the previous higher levels again (Fig. 15). The background signal did not change when sampling around clouds, suggesting that this effect was not an instrumental artefact. Studies of a similar FAGE instrument have shown no response of the instrument sensitivity to aerosol loading (Whalley et al., 2010). Modelling studies have shown that gaseous $\mathrm{HO}_{2}$ concentrations can be significantly reduced by aqueous phase chemistry, specifically through the efficient uptake of

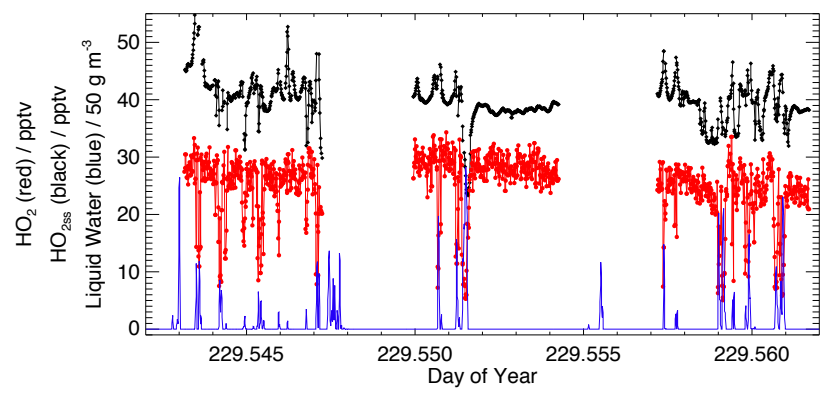

Fig. 15. Time Series of $\mathrm{HO}_{2}$ variation in Cloud. $\mathrm{HO}_{2}(1 \mathrm{~s}$, pptv, red), $\mathrm{HO}_{2} \mathrm{ss}(1 \mathrm{~s}$, pptv, black), scaled Nevzorov probe liquid water content $\left(\mathrm{g} \mathrm{m}^{-3} \times 50\right)$ (blue). Data were taken between 13:00 and 13:30 UTC at a constant altitude of $1.5 \mathrm{~km}$ over northern Benin $\left(10.9^{\circ}-12.5^{\circ} \mathrm{N}\right)$.

$\mathrm{HO}_{2}$ onto cloud droplets (Tilgner et al., 2005). These aqueous phase models combine detailed microphysics and multiphase chemistry, but few experimental observations exist to validate the model calculated depletion of radical species in clouds. Figure 15 shows the $1 \mathrm{~s}$ time series of the observed $\mathrm{HO}_{2}$, steady state calculated $\mathrm{HO}_{2}$ ss mixing ratios and the Liquid Water Content (LWC, $\mathrm{g} \mathrm{m}^{-3}$ ) observed between 13:00 and 13:30 UTC at a constant altitude of $1.5 \mathrm{~km}$ over northern Benin (10.9-12.5 N) (Flight B235A, $17 \mathrm{Au}-$ gust 2006). The timing of the short-lived reduction in $\mathrm{HO}_{2}$ observed when sampling in cloud is reproduced by $\mathrm{HO}_{2}$ ss but, as seen earlier, $\mathrm{HO}_{2}$ ss is consistently greater than $\mathrm{HO}_{2}$. Much of the variability in $\mathrm{HO}_{2}$ ss is driven by changes in $J\left(\mathrm{O}^{1} \mathrm{D}\right)$, which varied greatly in and out of cloud, depending on the cloud thickness. $\mathrm{O}_{3}$ was generally found to decrease in cloud, while the fraction of $\mathrm{O}\left({ }^{1} \mathrm{D}\right)$ reacting with $\mathrm{H}_{2} \mathrm{O}$ vapour to form $\mathrm{OH}\left(F_{\mathrm{OH}}\right)$ generally increased quickly due to higher water vapour, counteracting the decrease in ozone and $J\left(\mathrm{O}^{1} \mathrm{D}\right)$ to an extent. Overall these fast changes in $P(\mathrm{OH})$ resulted in reductions in $\mathrm{HO}_{2 \mathrm{ss}}$. However, the observed reduction in $\mathrm{HO}_{2}$ was much greater than that seen in $\mathrm{HO}_{2}$ ss. Thus the relative change in the $\mathrm{HO}_{2} / \mathrm{HO}_{2}$ ss ratio is considered for each cloud encounter, as this removes any variation due to changes in the $\mathrm{HO}_{\mathrm{x}}$ production rates.

Figure 16a shows the $1 \mathrm{~Hz}$ time series of the $\mathrm{HO}_{2} / \mathrm{HO}_{2}$ ss ratio and the simultaneously observed liquid water content. The magnitude of the short-lived decreases in $\mathrm{HO}_{2}$ inside the cloud are not reproduced in the calculated $\mathrm{HO}_{2}$ ss, resulting in a decrease in the $\mathrm{HO}_{2} / \mathrm{HO}_{2}$ ss ratio. These rapid decreases in the $\mathrm{HO}_{2} / \mathrm{HO}_{2}$ ss ratio generally coincide with increases in liquid water and may be due to the heterogeneous uptake of $\mathrm{HO}_{2}$ onto the cloud aerosol surface. Figure 16b shows the $\mathrm{HO}_{2} / \mathrm{HO}_{2}$ ss ratio as a function of liquid water content. While the values of $\mathrm{HO}_{2} / \mathrm{HO}_{2}$ ss ratio are highly variable, the highest ratios (median of 0.47) are found for low liquid water (below $0.2 \mathrm{~g} \mathrm{~m}^{-3}$ ), and the lowest ratios (median of 0.25 ) are found for higher liquid water content (greater than $0.2 \mathrm{~g} \mathrm{~m}^{-3}$ ). 

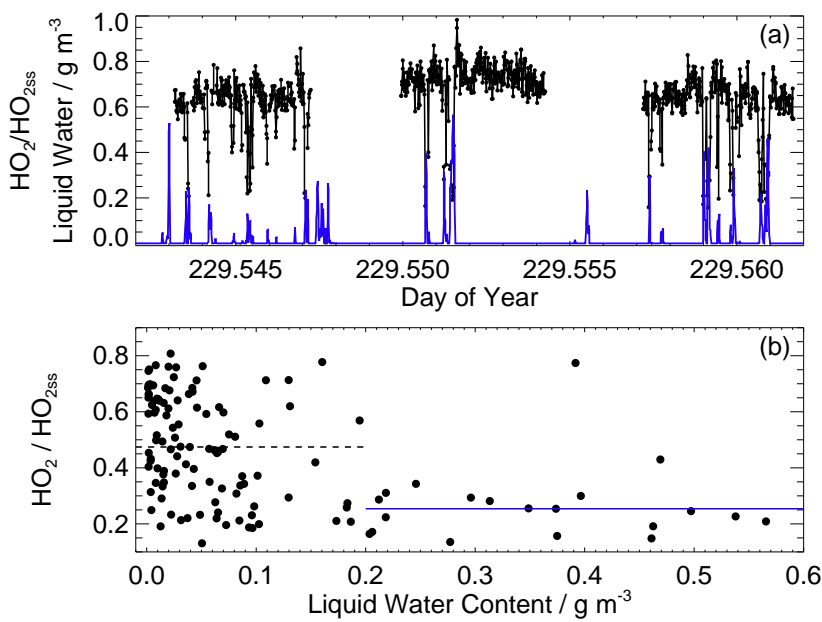

Fig. 16. (a) Time Series of $\mathrm{HO}_{2} / \mathrm{HO}_{2}$ ss ratio (black) and liquid water (blue); (b) $\mathrm{HO}_{2} / \mathrm{HO}_{2}$ ss ratio as a function of liquid water $\left(\mathrm{g} \mathrm{m}^{-3}\right)$. The median $\mathrm{HO}_{2} / \mathrm{HO}_{2}$ ss ratio is 0.4 and is shown as a dashed line.

The reduction in $\mathrm{HO}_{2}$ in clouds has been observed previously using both FAGE and CIMS instruments (e.g. Mauldin et al., 1999; Olson et al., 2004), and this loss of $\mathrm{HO}_{2}$ has been attributed to heterogeneous uptake of $\mathrm{HO}_{2}$ onto the cloud aerosol. During the TRACE-P (Transport and Chemical Evolution over the Pacific) campaign, Olson et al. (2004) found that the observed $\mathrm{HO}_{2}$ was much lower than that calculated by a comprehensive chemistry model, especially within clouds. For each 1 min data point, observations within cloud were identified. The observed-to-modelled $\mathrm{HO}_{2}$ ratio was found to significantly reduce when sampling clouds with an increased liquid water content but appeared to be independent of the duration of cloud sampling. The time resolution of many species required to calculate $\mathrm{HO}_{2}$ in chemical models is too low to interpret the short-lived depletions in $\mathrm{HO}_{2}$ observed during AMMA (e.g. minimum $15 \mathrm{~s}$ for isoprene observed by PTR-MS). Therefore these rapid reductions in $\mathrm{HO}_{2}$ are unlikely to provide any more than a qualitative sense of the heterogeneous uptake of $\mathrm{HO}_{2}$ by cloud droplets.

The impact of $\mathrm{HO}_{2}$ loss due to uptake on liquid cloud was investigated. The first order loss to surfaces was calculated with the diffusion of cloud droplets included (Schwartz, 1984):

$k^{\prime}$ loss $=\frac{A}{\frac{4}{c_{\mathrm{g}} \gamma}+\frac{r}{D_{\mathrm{g}}}}$

where $k^{\prime}$ loss is the rate constant for the loss of $\mathrm{HO}_{2}$ to cloud droplets $\left(\mathrm{s}^{-1}\right), A$ is the cloud droplet surface area per unit volume $\left(\mathrm{m}^{2} \mathrm{~m}^{-3}\right), \gamma$ is the uptake coefficient to liquid water, $r$ is the droplet radius (m) and $D_{\mathrm{g}}$ is the diffusion coefficient (for cloud droplets $\sim 1 \times 10^{-6} \mathrm{~m}^{2} \mathrm{~s}^{-1}$, Ravishankara, 1997). The uptake of $\mathrm{HO}_{2}$ onto cloud is not tightly constrained and the uptake coefficient is thought to vary between 0.1 and 1
(Jacob, 2000; Morita et al., 2004). The mean molecular speed of the gas, $c_{\mathrm{g}}\left(\mathrm{m} \mathrm{s}^{-1}\right)$ is:

$c_{\mathrm{g}}=\sqrt{\frac{8 R T}{\pi M_{\mathrm{w}}}}$

where $R$ is the universal gas constant, $T$ is the temperature and $M_{\mathrm{w}}$ is the molecular weight of $\mathrm{HO}_{2}$.

Unfortunately no information was available on the size or number concentration of cloud droplets encountered for the observation period examined here but the $\mathrm{HO}_{\mathrm{x}}$ observations were made over the continent of West Africa and typical continental values of cloud droplet size $(10 \mu \mathrm{m})$ and concentration $\left(1.5 \times 10^{8}\right.$ droplets $\left.\mathrm{m}^{-3}\right)$ have been assumed in the calculation of $k^{\prime}$ loss (Wallace and Hobbs, 2002). The main production and loss mechanisms of $\mathrm{HO}_{2}$ were calculated for all $\mathrm{HO}_{2}$ data where the liquid water content was greater than $0.2 \mathrm{~g} \mathrm{~m}^{-3}$ and an assumed mid-range $\gamma$ of 0.5 .

Using these constraints, the mean rate of $\mathrm{HO}_{2}$ loss to cloud droplets was calculated to be $4.2 \times 10^{6}$ molecule $\mathrm{cm}^{-3} \mathrm{~s}^{-1}$, slightly greater than the primary production rate $\left(4.1 \times 10^{6}\right.$ molecule $\left.\mathrm{cm}^{-3} \mathrm{~s}^{-1}\right)$ but much larger than the $\mathrm{HO}_{2}$ self reaction $\left(0.89 \times 10^{6}\right.$ molecule $\left.\mathrm{cm}^{-3} \mathrm{~s}^{-1}\right)$. Therefore it is reasonable to assume that the uptake of $\mathrm{HO}_{2}$ onto cloud droplets is a major sink of $\mathrm{HO}_{2}$ within a cloud. Without the inclusion of $\mathrm{HO}_{2}$ uptake on clouds, the mean steady state calculated $\mathrm{HO}_{2}$ mixing ratio, $\mathrm{HO}_{2}$ ss, is $35 \mathrm{pptv}$, much higher than the observed mean $\mathrm{HO}_{2}$ mixing ratio of $10.6 \mathrm{pptv}$. It is possible to calculate a cloud-influenced $\mathrm{HO}_{2}$ mixing ratio, $\mathrm{HO}_{2}$ cloud, assuming that the primary production of $\mathrm{HO}_{2}$ (through $\mathrm{OH}$ ) is equal to the loss of $\mathrm{HO}_{2}$ from both self reaction and uptake on clouds:

$\mathrm{P}(\mathrm{OH})=k^{\prime}{ }_{\text {loss }}\left[\mathrm{HO}_{2}\right]+2 k_{\mathrm{HO}_{2}}+\mathrm{HO}_{2}\left[\mathrm{HO}_{2}\right]^{2}$

With the inclusion of $\mathrm{HO}_{2}$ uptake onto cloud droplets in the calculation of $\mathrm{HO}_{2}$, the mean $\mathrm{HO}_{2}$ cloud mixing ratio was calculated to be $8.84 \mathrm{pptv}$, in closer agreement with the mean observed $\mathrm{HO}_{2}$ mixing ratio (10.6 pptv), than the previous steady state calculation of $35 \mathrm{pptv}$.

In order to fully understand the role of clouds on the oxidative capacity of the troposphere, a more comprehensive field study of $\mathrm{HO}_{2}$ uptake by clouds is required. The cloud droplet radius, surface area and the concentration of droplets should be measured at the same time resolution as $\mathrm{HO}_{2}$ observations. In parallel with field studies, laboratory studies are needed to reduce the large uncertainty in current estimates of the $\mathrm{HO}_{2}$ cloud uptake coefficient $(\gamma)$, which, at present, limits our understanding of $\mathrm{HO}_{2}$ behaviour in clouds.

\section{2 $\mathrm{HO}_{2}$ at night}

$\mathrm{HO}_{2}$ was observed at night on a number of flights over the forested region but no $\mathrm{HO}_{2}$ data was collected over the Sahel region or ocean at night. A maximum $\mathrm{HO}_{2}$ mixing ratio of 9.2 pptv was observed in the hour after sunset and a median 


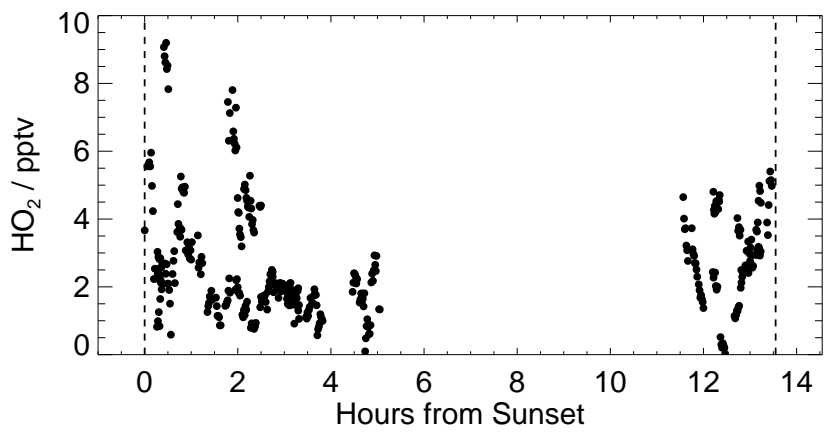

Fig. 17. $\mathrm{HO}_{2}$ time series as a function of time from sunset. Dawn and dusk are indicated by dashed lines.

$\mathrm{HO}_{2}$ mixing ratio of $2.2 \mathrm{pptv}$ observed overall at night. Isoprene reached up to $1 \mathrm{ppbv}$ at night in areas north of the most heavily forested region, with the highest mixing ratios coincident with the highest $\mathrm{HO}_{2}$ mixing ratios. This night-time maximum in isoprene at latitudes north of the day-time maximum is consistent with transport of the airmass north with the monsoon winds (Murphy et al., 2010).

Figure 17 shows the time series of $\mathrm{HO}_{2}$ after sunset, showing that $\mathrm{HO}_{2}$ mixing ratios decrease as the night progresses, with the suggestion of an increase again just before dawn.

At night $\mathrm{HO}_{2}$ can be generated from the ozonolysis of alkenes, (e.g. isoprene) and terpenes (e.g. Kroll, 2002). Isoprene emissions are strongly dependent on sunlight, unlike terpene emissions which are also a function of temperature (Guenther et al., 2006). When night-time temperatures remain high, terpene emission may continue into the night and the reaction of these alkenes and terpenes with ozone leads to the production of $\mathrm{HO}_{\mathrm{x}}$. Mixing ratios of $\mathrm{HO}_{2}$ in excess of that reported here have been observed at night previously at surface sites (e.g. 1-4 pptv $\mathrm{HO}_{2}$ was observed in midlatitude deciduous forest (Faloona et al., 2001), up to $10 \mathrm{pptv}$ $\mathrm{HO}_{2}$ was observed on Rishiri Island, Japan, (Kanaya et al., 2002) and over 10 pptv $\mathrm{HO}_{2}$ observed in China, Hofzumahaus et al., 2009). However, no altitude profiles of night-time $\mathrm{HO}_{2}$ have been reported previously.

Figure 18 shows the altitude profile of (a) $\mathrm{HO}_{2}$ (pptv), and (b) $\mathrm{O}_{3}$ (ppbv) observed at night. The greatest $\mathrm{HO}_{2}$ mixing ratio observed (less than an hour after dusk) was within $500 \mathrm{~m}$ of the surface. $\mathrm{O}_{3}$ mixing ratios were lowest $(<20 \mathrm{pptv})$ at the surface and increased steadily with altitude through the boundary layer. Isoprene, emitted from the surface, and Methyl Vinyl Ketone (MVK), a degradation product of isoprene, were highest in the boundary layer and generally decreased with altitude. This suggests that alkene ozonolysis may play a role as a source of $\mathrm{HO}_{2}$ at night in the forest boundary layer. Between 6 and $8 \mathrm{~km}$, both isoprene and MVK were observed to increase slightly. As there is no source of isoprene at these altitudes, these species may have been convectively injected into the mid troposphere (Murphy

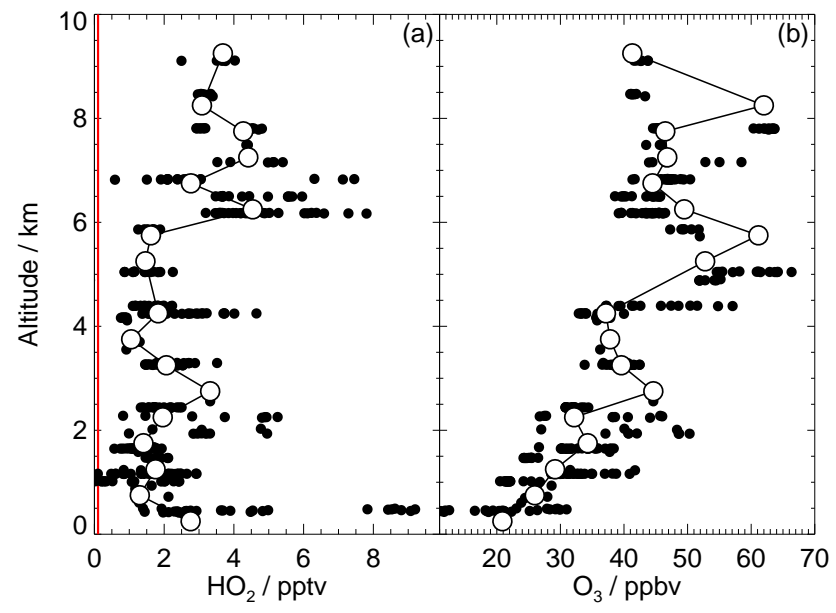

Fig. 18. Night-time Altitude Profiles of (a) $\mathrm{HO}_{2}$ (pptv, black) and maximum $\mathrm{HO}_{2}$ limit of detection (pptv, red) for the night-time dataset. (b) $\mathrm{O}_{3}$ (ppbv). Median values for $500 \mathrm{~m}$ altitude bins are shown as white circles.

et al., 2010), resulting in the production of $\mathrm{HO}_{2}$ at higher altitude at night.

\section{3 $\mathrm{OH}$ and $\mathrm{HO}_{2}$ with isoprene}

Figure 19 shows the latitudinal variation of $\mathrm{OH}$ and $\mathrm{HO}_{2}$ and highlights how the maximum mixing ratios of both $\mathrm{OH}$ and $\mathrm{HO}_{2}$ were found in the boundary layer of the southern end of the forest region. The West African Monsoon (WAM) brings the majority of rainfall to the continent and produces a strong latitudinal gradient in vegetation and biogenic emissions such as isoprene: Murphy et al. (2010) show that the highest mixing ratios of isoprene were observed in the boundary layer above the southern forest regions $\left(9-11^{\circ} \mathrm{N}\right)$.

Modelling studies of the latitudinal gradient of West Africa predict minimal $\mathrm{HO}_{\mathrm{x}}$ concentrations over the forested regions due to isoprene scavenging of $\mathrm{OH}$ (Saunois et al., 2009). Isoprene reacts quickly with $\mathrm{OH}$ $\left(k=1.0 \times 10^{-10} \mathrm{~cm}^{3} \mathrm{~s}^{-1}\right.$ at $294 \mathrm{~K}$; Karl et al., 2004) and, given the concentrations of isoprene in the boundary layer above forests, this reaction should result in significant depletion of $\mathrm{OH}$.

However, the observations presented here suggest that neither $\mathrm{OH}$ nor $\mathrm{HO}_{2}$ mixing ratios are significantly depleted. Lelieveld et al. (2008) also observed higher than expected mixing ratios of $\mathrm{HO}_{\mathrm{x}}$ over forests in Suriname and suggested that additional production of $\mathrm{OH}$ from the degradation products of isoprene (Dillon and Crowley, 2008; Peeters et al., 2009; Paulot et al., 2009; da Silva et al., 2010) could explain the high concentrations of $\mathrm{HO}_{\mathrm{x}}$. Given the complex nature of the oxidation of VOCs, the interpretation of these $\mathrm{HO}_{\mathrm{x}}$ mixing ratios requires a more comprehensive modelling study than presented here. Stone et al. (2010) presents a detailed chemical box modelling study, based on the Master Chemical 

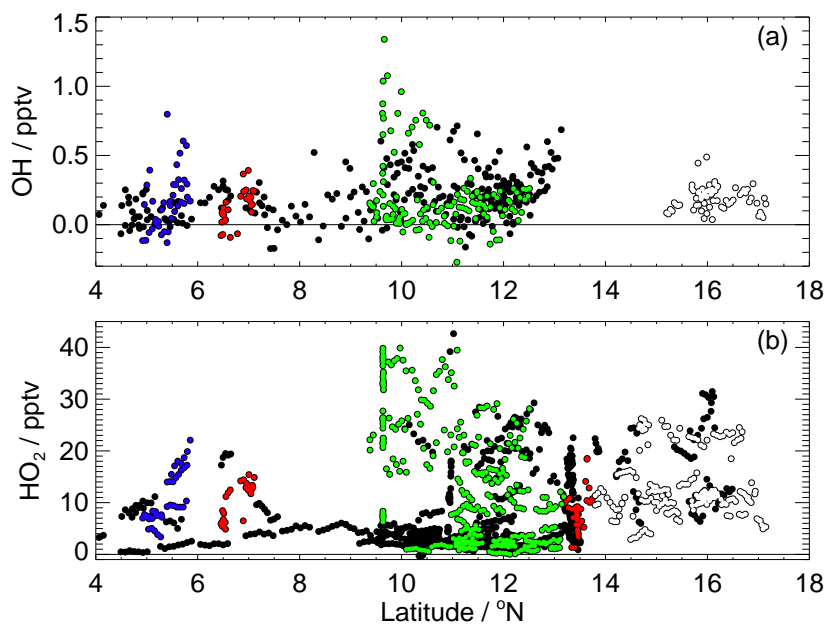

Fig. 19. Latitudinal variation of (a) $\mathrm{OH}$ and (b) $\mathrm{HO}_{2}$ mixing ratio. Observations in the boundary layer are shown for data collected above the Sahel $\left(13.75^{\circ}-18^{\circ} \mathrm{N}\right.$, white), Forest $\left(7.3^{\circ}-\right.$ $13.2^{\circ} \mathrm{N}$, green $)$, Ocean $\left(4^{\circ}-6^{\circ} \mathrm{N}\right.$, blue) and Urban areas $\left(6^{\circ}-7.3^{\circ} \mathrm{N}\right.$ and $13.2^{\circ}-13.75^{\circ} \mathrm{N}$, red). Observations in the free troposphere in all regions are shown in black.

Mechanism (Saunders et al., 2003), to explore the interpretation of the $\mathrm{HO}_{\mathrm{x}}$ observations presented here.

\subsection{Biomass burning plume}

As shown in Figs. 13 and 14, $\mathrm{OH}$ and $\mathrm{HO}_{2}$ sampled in a biomass burning plume showed some of the largest disagreement for the steady state calculations. The two distinct biomass burning episodes identified in Fig. 14 are from 22 July and 8 August 2006. The data from 8 August (observed $\mathrm{HO}_{2}<$ calculated $\mathrm{HO}_{2}$ ) is examined in more detail as there are more observations of both $\mathrm{HO}_{2}$ and other data available. There is no $\mathrm{NO}_{\mathrm{X}}$ data available for the five data points identified as biomass burning on 22 July (observed $\mathrm{HO}_{2}>$ calculated $\mathrm{HO}_{2}$ ).

During the 8 August episode, the biomass burning plume was sampled at two altitudes over the Gulf of Guinea. At an altitude of $4-5 \mathrm{~km}$, the mean $\mathrm{O}_{3}$ mixing ratio was $50 \mathrm{ppbv}$ and the mean $\mathrm{CO}$ mixing ratio was $150 \mathrm{ppbv}$. At an altitude of $3.5 \mathrm{~km}$, mixing ratios of $\mathrm{O}_{3}$ and $\mathrm{CO}$ were some of the highest observed during the campaign (100 ppbv and 300 ppbv respectively). Coincident with these observations was a sharp increase in $\mathrm{NO}$, acetonitrile $\left(\mathrm{CH}_{3} \mathrm{CN}\right)$ and Peroxyacetyl Nitrate (PAN). Acetonitrile has been identified as a tracer for airmasses affected by biomass burning (de Gouw et al., 2003).

Figure 20 shows the time series of $\mathrm{O}_{3}, \mathrm{CO}, \mathrm{OH}$ and $P(\mathrm{OH})$ and $\mathrm{HO}_{2}$ and $\mathrm{HO}_{2}$ ss. The biomass burning plume was sampled at two altitudes, with the highest concentrations of both $\mathrm{O}_{3}$ and $\mathrm{CO}$ observed at an altitude of $3-4 \mathrm{~km}$ (indicated as $\mathrm{BB}$ between the blues dashed lines). Within the plume at

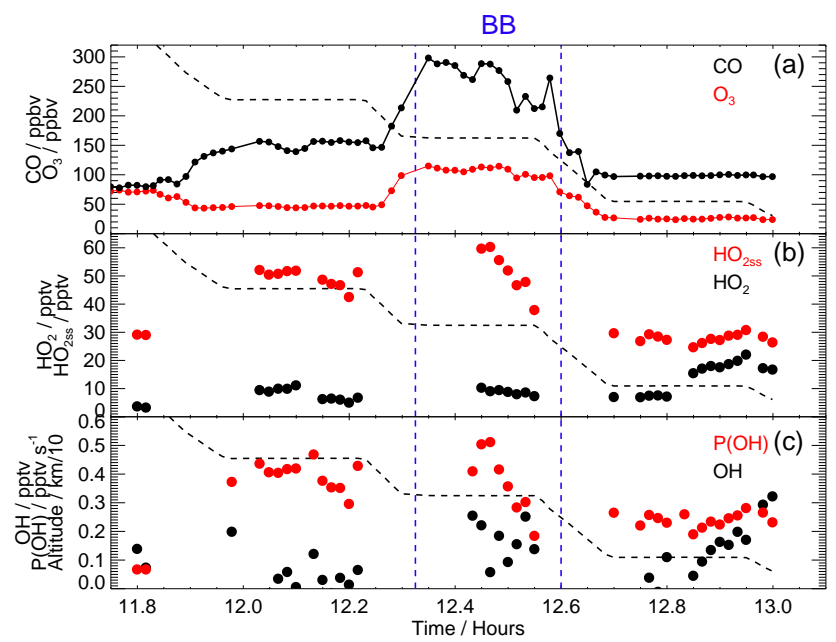

Fig. 20. Time series within and around a biomass burning (BB) plume with (a) $\mathrm{CO}$ (ppbv, black), and $\mathrm{O}_{3}$ (ppbv, red), (b) $\mathrm{HO}_{2}$ (pptv, black) and $\mathrm{HO}_{2}$ ss (pptv, red), (c) $\mathrm{OH}$ (pptv, black) and $\mathrm{P}(\mathrm{OH})$ (pptv s ${ }^{-1}$, red). On all graphs altitude is indicated by a black dashed line. All data are averaged to $60 \mathrm{~s}$.

$3.5 \mathrm{~km}$, mixing ratios of $400 \mathrm{pptv} \mathrm{CH}_{3} \mathrm{CN}$ (up from $100 \mathrm{pptv}$ outside the plume), 600 pptv PAN (up from 50 pptv outside the plume) and 200 pptv NO (up from 50 pptv outside the plume) were observed. Between $4.5 \mathrm{~km}$ and $3.5 \mathrm{~km}$, NO mixing ratios were found to increase from $150 \mathrm{pptv}$ to $200 \mathrm{pptv}$, which is consistent with an increase in the observed $\mathrm{OH}$ at the lower altitude. The calculation of $\mathrm{HO}_{2}$ ss does not incorporate the loss of $\mathrm{HO}_{\mathrm{x}}$ through reactions such as $\mathrm{RO}_{2}+\mathrm{HO}_{2}$, $\mathrm{OH}+\mathrm{VOC}, \mathrm{OH}+\mathrm{NO}_{2}$ or reactions with aerosols, so it is not surprising that $\mathrm{HO}_{2}$ ss is significantly higher than the observed $\mathrm{HO}_{2}$.

Previous observations of VOCs within aged biomass burning plumes (de Gouw et al., 2003) found that the $\mathrm{OH}$ inferred from the degradation of species such as benzene and toluene was a factor of 4 lower than that calculated by a OH climatology model (Spivakovsky et al., 2000). While Forberich et al. (1996) measured reduced levels of $\mathrm{OH}$ in a biomass burning plume on one afternoon, a systematic observation of oxidation in biomass burning plumes would help in our understanding of these events. Little biomass burning takes place in West Africa during the monsoon wet season. Within the plume, NO mixing ratios reach a maximum of 200 pptv $\left(\mathrm{NO}_{2}\right.$ observations were not available at this time), while PAN mixing ratios increased to over 600 pptv, suggesting that the biomass burning plume was transported from the Southern Hemisphere (Thouret et al., 2009; Liousse et al., 2010).

In this plume, $\mathrm{HO}_{2}$ mixing ratios are much lower than $\mathrm{HO}_{2}$ ss, as expected as $\mathrm{HO}_{2}$ ss does not include all possible $\mathrm{HO}_{\mathrm{x}}$ loss processes. The reaction of $\mathrm{OH}$ with $\mathrm{CO}$ forms $\mathrm{HO}_{2}$, thus conserving the $\mathrm{HO}_{\mathrm{x}}$ budget. However, the reaction of $\mathrm{OH}$ with any of the VOCs enhanced in this plume 
does not immediately form $\mathrm{HO}_{\mathrm{x}}$ and results in localised $\mathrm{HO}_{\mathrm{x}}$ depletion. The mixing ratios of a number of VOCs were observed to be greatly increased within the plume compared to outside the plume. Within the plume the greatest increase was observed in acetylene (factor of 7.5), followed by methanol (4.2), acetonitrile (3), benzene (2.9), ethane (2.9) and acetone (2.4). The $\mathrm{CO}$ mixing ratio increased from a mean of $98 \mathrm{ppbv}$ outside the plume to $245 \mathrm{ppbv}$ within the plume. The rate of production of $\mathrm{HO}_{2}$ from the $\mathrm{OH}$ reaction with $\mathrm{CO}$ can be compared to the rate of production of $\mathrm{RO}_{2}$ through the reaction of $\mathrm{OH}$ with VOCs.

The reactivity of $\mathrm{OH}$ with various VOCs can be estimated as a fraction of the $\mathrm{OH}$ reactivity with $\mathrm{CO}$ :

$$
R_{\mathrm{VOC}}=\frac{\sum^{i} k_{i}[\mathrm{VOC}]_{i}}{k_{\mathrm{CO}+\mathrm{OH}}}[\mathrm{CO}]
$$

where $k_{i}$ is the rate constant for the reaction of the $\mathrm{VOC}_{i}$ with $\mathrm{OH}$ and $\sum^{i} k_{i}[\mathrm{VOC}]_{i}$ is the sum over all the products of the VOC concentration and the appropriate rate coefficient for the reaction of $\mathrm{OH}$ with the VOC in question. From this ratio, the impact of enhanced VOC concentrations on $\mathrm{OH}$ can be examined. The VOC/CO ratio was found to be 1.6 times higher within the plume (71) than outside (43), consistent with the observed $\mathrm{HO}_{\mathrm{x}}$ depletion within the plume.

\section{Conclusions}

The Leeds aircraft FAGE instrument successfully measured tropospheric $\mathrm{OH}$ and $\mathrm{HO}_{2}$ over west Africa during the summer monsoon in 2006. The instrument was deployed aboard the BAe-146 research aircraft as part of the African Monsoon Multidisciplinary Analyses (AMMA) campaign. For calibrations, known concentrations of $\mathrm{HO}_{\mathrm{x}}$ were generated by the photolysis of water vapour by a mercury lamp, with the lamp flux determined by NO actinometry. The instrument sensitivity did not change appreciably over the pressure range observed in the fluorescence cell during the campaign (1.5-2.1 Torr). The mean instrumental limit of detection observed during the campaign was $7.1 \times 10^{5}$ molecule $\mathrm{cm}^{-3}$ for $\mathrm{OH}\left(60 \mathrm{~s}\right.$ integration time) and $7.5 \times 10^{5}$ molecule $\mathrm{cm}^{-3}$ for $\mathrm{HO}_{2}$ (60 s integration time).

$\mathrm{HO}_{\mathrm{x}}$ observations were made during 13 flights, ranging from $50 \mathrm{~m}$ to over $9 \mathrm{~km}$. The aircraft sampled air over the Sahel $\left(18^{\circ} \mathrm{N}\right)$, forest $\left(8^{\circ}-12^{\circ} \mathrm{N}\right)$ and over the ocean $\left(4^{\circ} \mathrm{N}\right)$. $\mathrm{OH}$ and $\mathrm{HO}_{2}$ mixing ratios show a diurnal profile but were highly variable. Observations of $\mathrm{OH}$ and $\mathrm{HO}_{2}$ were compared with steady state calculation of $\mathrm{HO}_{\mathrm{x}}$ and differences highlighted a number of case studies. $\mathrm{HO}_{2}$ data recorded at $1 \mathrm{~Hz}$ showed evidence of rapid reductions in the observed $\mathrm{HO}_{2}$ in and around cloud, which could not be explained by changing primary production rates within the cloud. The heterogeneous uptake of $\mathrm{HO}_{2}$ onto the cloud surface was included in the steady state $\mathrm{HO}_{\mathrm{x}}$ calculation and improved the agreement with the observed short-lived reductions of $\mathrm{HO}_{2}$ in cloud. However, a more comprehensive field study of $\mathrm{HO}_{2}$ and the properties of cloud droplets is required to fully understand the role of clouds on the oxidative capacity of the troposphere. Mixing ratios of $\mathrm{HO}_{2}$ of 9 pptv were observed at night and the first altitude profile of $\mathrm{HO}_{2}$ at night is presented. Up to 7 pptv of $\mathrm{HO}_{2}$ was observed above $6 \mathrm{~km}$, consistent with the convective uplift of $\mathrm{HO}_{2}$ precursors such as isoprene. High mixing ratios of $\mathrm{OH}$ and $\mathrm{HO}_{2}$ were observed in areas of high isoprene, in sharp contrast to the depletion calculated by models. Within a biomass burning plume, $\mathrm{HO}_{\mathrm{x}}$ was found to be depleted. Calculations show that $\mathrm{OH}$ was 1.6 times more likely to react with VOCs than $\mathrm{CO}$, resulting in the observed depletion of $\mathrm{HO}_{\mathrm{x}}$.

Acknowledgements. The authors would like to thank M. Darling and the staff of Avalon Aero for help in the integration of the instrument and Jack Fox and NCAR workshops for the design and manufacture of the inlet. Thanks to the staff of FAAM, Directflight and the AMMA AOC for all of their hard work in making the detachment possible. We would like to thank all of the scientists who worked on the BAe-146 for their hard work in making this project a success. We thank D. Brookes and P. Monks (University of Leicester) for providing $J\left(\mathrm{O}^{1} \mathrm{D}\right)$ data, J. Murphy and D. Oram (University of East Anglia) for providing isoprene and acetonitrile data, D. Stewart (University of East Anglia) for $\mathrm{NO}_{\mathrm{x}}$ data, J. McQuaid (University of Leeds) for PAN data and A. Lewis, J. Lee and J. Hopkins (University of York) for hydrocarbon data.

Based on a French initiative, AMMA was built by an international scientific group and was funded by a large number of agencies, especially from France, the UK, the US and Africa. This work was funded by the EU and by the UK Natural Environment Research Council through the AMMA-UK Consortium grant and the National Centre for Atmospheric Science.

Edited by: P. Formenti

\section{References}

Andrés-Hernández, M. D., Stone, D., Brookes, D. M., Commane, R., Reeves, C. E., Huntrieser, H., Heard, D. E., Monks, P. S., Burrows, J. P., Schlager, H., Kartal, D., Evans, M. J., Floquet, C. F. A., Ingham, T., Methven, J., and Parker, A. E.: Peroxy radical partitioning during the AMMA radical intercomparison exercise, Atmos. Chem. Phys. Discuss., 10, 8447-8486, doi:10.5194/acpd-10-8447-2010, 2010.

Bloss, W. J., Evans, M. J., Lee, J. D., Sommariva, R., Heard, D. E., and Pilling, M. J.: The oxidative capacity of the troposphere: Coupling of field measurements of $\mathrm{OH}$ and a global chemistry transport model, Faraday Discuss., 130, 425-436, doi:10.1039/ b419090d, 2005.

Butler, T. M., Taraborrelli, D., Brühl, C., Fischer, H., Harder, H., Martinez, M., Williams, J., Lawrence, M. G., and Lelieveld, J.: Improved simulation of isoprene oxidation chemistry with the ECHAM5/MESSy chemistry-climate model: lessons from the GABRIEL airborne field campaign, Atmos. Chem. Phys., 8, 4529-4546, doi:10.5194/acp-8-4529-2008, 2008. 
Capes, G., Murphy, J. G., Reeves, C. E., McQuaid, J. B., Hamilton, J. F., Hopkins, J. R., Crosier, J., Williams, P. I., and Coe, H.: Secondary organic aerosol from biogenic VOCs over West Africa during AMMA, Atmos. Chem. Phys., 9, 3841-3850, doi:10.5194/acp-9-3841-2009, 2009.

Cantrell, C. A., Shetter, R. E., Calvert, J. G., and Tanner, F. L. E. A. J.: Some considerations of the origin of nighttime peroxy radicals observed in MLOPEX, J. Geophys. Res.-Atmos., 102, 15899-15913, 1997.

Creasey, D. J., Heard, D. E., Pilling, M. J., Whitaker, B. J., Berzins, M., and Fairlie, R.: Visualisation of a supersonic free-jet expansion using laser-induced fluorescence spectroscopy: Application to the measurement of rate constants at ultralow temperatures, Appl. Phys. B, 65, 375-392, 1997.

Creasey, D. J., Heard, D. E., and Lee, J. D.: Eastern Atlantic Spring Experiment 1997 (EASE97), 1. Measurements of $\mathrm{OH}$ and $\mathrm{HO}_{2}$ concentrations at Mace Head, Ireland, J. Geophys. Res.-Atmos., 107, 4091, doi:10.1029/2001JD000892, 2002.

Crawford, J., Davis, D., Olson, J., Chen, G., Liu, S., Gregory, G., Barrick, J., Sachse, G., Sandholm, S., Heikes, B., Singh, H., and Blake, D.: Assessment of upper tropospheric $\mathrm{HO}_{\mathrm{x}}$ sources over the tropical Pacific based on NASA GTE/PEM data: Net effect on $\mathrm{HO}_{\mathrm{x}}$ and other photochemical parameters, J. Geophys. Res.Atmos., 104, 16255-16273, 1999.

da Silva, G., Graham, C., and Wang, Z.-F.: Unimolecular $\beta$ Hydroxyperoxy Radical Decomposition with $\mathrm{OH}$ Recycling in the Photochemical Oxidation of Isoprene, Environ. Sci. Technol., 44, 250-256, 2010.

de Gouw, J. A., Warneke, C., Parrish, D. D., Holloway, J. S., Trainer, M., and Fehsenfeld, F. C.: Emission sources and ocean uptake of acetonitrile $\left(\mathrm{CH}_{3} \mathrm{CN}\right)$ in the atmosphere, J. Geophys. Res., 108, 4329, doi:10.1029/2002JD002897, 2003.

Dillon, T. J. and Crowley, J. N.: Direct detection of OH formation in the reactions of $\mathrm{HO}_{2}$ with $\mathrm{CH}_{3} \mathrm{C}(\mathrm{O}) \mathrm{O}_{2}$ and other substituted peroxy radicals, Atmos. Chem. Phys., 8, 4877-4889, doi:10.5194/acp-8-4877-2008, 2008.

Dusanter, S., Vimal, D., Stevens, P. S., Volkamer, R., Molina, L. T., Baker, A., Meinardi, S., Blake, D., Sheehy, P., Merten, A., Zhang, R., Zheng, J., Fortner, E. C., Junkermann, W., Dubey, M., Rahn, T., Eichinger, B., Lewandowski, P., Prueger, J., and Holder, $\mathrm{H}$.: Measurements of $\mathrm{OH}$ and $\mathrm{HO}_{2}$ concentrations during the MCMA-2006 field campaign - Part 2: Model comparison and radical budget, Atmos. Chem. Phys., 9, 6655-6675, doi:10.5194/acp-9-6655-2009, 2009.

Edwards, G., Cantrell, C., Stephens, S., Hill, B., Goyea, O., Shetter, R., Mauldin, R., Kosciuch, E., Tanner, D., and Eisele, F.: Chemical Ionization Mass Spectrometer Instrument for the Measurement of Tropospheric $\mathrm{HO}_{2}$ and $\mathrm{RO}_{2}$, Anal. Chem., 75, 53175327, 2003.

Ehhalt, D. H.: Photooxidation of trace gases in the troposphere, Phys. Chem. Chem. Phys., 1, 5401-5408, 1999.

Eisele, F. L., Mauldin, R. L., Tanner, D. J., Fox, J. R., Mouch, T., and Scully, T.: An inlet/sampling duct for airborne $\mathrm{OH}$ and sulfuric acid measurements, J. Geophys. Res.-Atmos., 102, 27993 28001, 1997.

Faloona, I., Tan, D., Brune, W., Hurst, J., Barket, D., Couch, T. L., Shepson, P., Apel, E., Riemer, D., Thornberry, T., Carroll, M. A., Sillman, S., Keeler, G. J., Sagady, J., Hooper, D., and Paterson, K.: Nighttime observations of anomalously high levels of hydroxyl radicals above a deciduous forest canopy, J. Geophys. Res.-Atmos., 106, 24315-24333, 2001.

Faloona, I. C., Tan, D., Lesher, R. L., Hazen, N. L., Frame, C. L., Simpas, J. B., Harder, H., Martinez, M., Di Carlo, P., Ren, X., and Brune, W. H.: A laser induced fluorescence instrument for detecting tropospheric $\mathrm{OH}$ and $\mathrm{HO}_{2}$ : Characteristics and calibration, J. Atmos. Chem., 47, 139-167, 2004.

Fehsenfeld, F., Calvert, J., Fall, R., Goldan, P., Guenther, A., Hewitt, C., Lamb, B., Liu, S., Trainer, M., Westberg, H., and Zimmerman, P.: Emissions of volatile organic compounds from vegetation and the implications for atmospheric chemistry., Global Biogeochem. Cy., 6, 389-430, 1992.

Forberich, W. J. and Comes, F. J.: Measurement of $\mathrm{OH}$ concentration during a forest fire episode: atmospheric implications for biomass burning, Chem. Phys. Lett., 259, 408-414, doi: 10.1016/0009-2614(96)00805-6, 1996.

Fuentes, J. D., Lerdau, M., Atkinson, R., Baldocchi, D., Bottenheim, J. W., Ciccioli, P., Lamb, B., Geron, C., Gu, L., Guenther, A., Sharkey, T. D., and Stockwell, W.: Biogenic hydrocarbons in the atmospheric boundary layer: A review, B. Am. Meteorol. Soc., 81, 1537-1575, 2000.

Glowacki, D. R., Goddard, A., Hemavibool, K., Malkin, T. L., Commane, R., Anderson, F., Bloss, W. J., Heard, D. E., Ingham, T., Pilling, M. J., and Seakins, P. W.: Design of and initial results from a Highly Instrumented Reactor for Atmospheric Chemistry (HIRAC), Atmos. Chem. Phys., 7, 5371-5390, 2007, http://www.atmos-chem-phys.net/7/5371/2007/.

Guenther, A., Hewitt, N. C., Erickson, D., Fall, R., Geron, C., Graedel, T., Harley, P., Klinger, L., Lerdau, M., McKay, W. A., Pierce, T., Scholes, B., Steinbrecher, R., Tallamraju, R., Taylor, J., and Zimmerman, P.: A global model of natural volatile organic compound emissions, J. Geophys. Res.-Atmos., 100, 8873-8892, 1995.

Guenther, A., Karl, T., Harley, P., Wiedinmyer, C., Palmer, P. I., and Geron, C.: Estimates of global terrestrial isoprene emissions using MEGAN (Model of Emissions of Gases and Aerosols from Nature), Atmos. Chem. Phys., 6, 3181-3210, doi:10.5194/acp-63181-2006, 2006.

Hard, T. M., O’Brien, R. J., Chan, C. Y., and Mehrabzadeh, A. A.: Tropospheric Free-Radical Determination by FAGE, Environ. Sci. Technol., 18, 768-777, 1984.

Heard, D. E. and Pilling, M. J.: Measurement of $\mathrm{OH}$ and $\mathrm{HO}_{2}$ in the Troposphere, Chem. Rev., 103, 5163-5198, 2003.

Hofzumahaus, A., Rohrer, F., Lu, K., Bohn, B., Brauers, T., Chang, C.-C., Fuchs, H., Holland, F., Kita, K., Kondo, Y., Li, X., Lou, S., Shao, M., Zeng, L., Wahner, A., and Zhang, Y.: Amplified Trace Gas Removal in the Troposphere, Science, 324, 1702-1704, doi: 10.1126/science.1164566, 2009.

Holland, F., Hofzumahaus, A., Schafer, R., Kraus, A., and Patz, H. W.: Measurements of $\mathrm{OH}$ and $\mathrm{HO}_{2}$ radical concentrations and photolysis frequencies during BERLIOZ, J. Geophys. Res.Atmos., 108, 8246, doi:10.1029/2001JD001393, 2003.

Hopkins, J. R., Evans, M. J., Lee, J. D., Lewis, A. C., H Marsham, J., McQuaid, J. B., Parker, D. J., Stewart, D. J., Reeves, C. E., and Purvis, R. M.: Direct estimates of emissions from the megacity of Lagos, Atmos. Chem. Phys., 9, 8471-8477, doi:10.5194/acp9-8471-2009, 2009.

Hurst, J. M., Barket, D. J., Herrera-Gomez, O., Couch, T. L., Shepson, P. B., Faloona, I., Tan, D., Brune, W., Westberg, H., Lamb, 
B., Biesenthal, T., Young, V., Goldstein, A., Munger, J. W., Thornberry, T., and Carroll, M. A.: Investigation of the nighttime decay of isoprene, J. Geophys. Res.-Atmos., 106, 24335-24346, 2001.

Jacob, D. J.: Heterogeneous chemistry and tropospheric ozone, Atmos. Environ., 34, 2131-2159, 2000.

Kanaya, Y., Nakamura, K., Kato, S., Matsumoto, J., Tanimoto, H., and Akimoto, $\mathrm{H}$.: Nighttime variations in $\mathrm{HO}_{2}$ radical mixing ratios at Rishiri Island observed with elevated monoterpene mixing ratios, Atmos. Environ., 36, 4929-4940, 2002.

Karl, M., Brauers, T., Dorn, H. P., Holland, F., Komenda, M., Poppe, D., Rohrer, F., Rupp, L., Schaub, A., and Wahner, A.: Kinetic Study of the $\mathrm{OH}$-isoprene and O-isoprene reaction in the atmosphere simulation chamber, SAPHIR, Geophys. Res. Lett., 31, L05117, doi:10.1029/2003GL019189, 2004.

Karl, T., Guenther, A., Yokelson, R. J., Greenberg, J., Potosnak, M., Blake, D. R., and Artaxo, P.: The Tropical forest and fire emissions experiment: Emission, Chemistry and transport of biogenic volatile organic compounds in the lower atmopsphere over Amazonia, J. Geophys. Res. Atmos., 112, D18302, doi:10.1029/2007JD008539, 2007.

Kesselmeier, J. and Staudt, M.: Biogenic volatile organic compounds (VOC): An overview on emission, physiology and ecology, J. Atmos. Chem., 33, 23-88, 1999.

Kroll, J. H., Donahue, N. M., Cee, V. J., Demerjian, K. L., and Anderson, J. G.: Gas-Phase Ozonolysis of Alkenes: Formation of OH from Anti Carbonyl Oxides, J. Am. Chem. Soc., 124, 85188519, doi:10.1021/ja0266060, 2002.

Kubistin, D., Harder, H., Martinez, M., Rudolf, M., Sander, R., Bozem, H., Eerdekens, G., Fischer, H., Gurk, C., Klpfel, T., Knigstedt, R., Parchatka, U., Schiller, C. L., Stickler, A., Taraborrelli, D., Williams, J., and Lelieveld, J.: Hydroxyl radicals in the tropical troposphere over the Suriname rainforest: comparison of measurements with the box model MECCA, Atmos. Chem. Phys. Discuss., 8, 15239-15289, doi:10.5194/acpd8-15239-2008, 2008.

Lelieveld, J., Butler, T. M., Crowley, J. N., Dillon, T. J., Fischer, H., Ganzeveld, L., Harder, H., Lawrence, M. G., Martinez, M., Taraborrelli, D., and Williams, J.: Atmospheric oxidation capacity sustained by a tropical forest, Nature, 452, 737-740, doi: 10.1038/nature06870, 2008.

Lelieveld, J., Peters, V., Dentener, F. J., and Krol, M.: Stability of tropospheric hydroxyl chemistry, J. Geophys. Res., 107, 4715, doi:10.1029/2002JD002272, 2002.

Liousse, C., Guillaume, B., Grégoire, J. M., Mallet, M., Galy, C., Pont, V., Akpo, A., Bedou, M., Castéra, P., Dungall, L., Gardrat, E., Granier, C., Konaré, A., Malavelle, F., Mariscal, A., Mieville, A., Rosset, R., Serça, D., Solmon, F., Tummon, F., Assamoi, E., Yoboué, V., and Van Velthoven, P.: Western african aerosols modelling with updated biomass burning emission inventories in the frame of the AMMA-IDAF program, Atmos. Chem. Phys. Discuss., 10, 7347-7382, doi:10.5194/acpd10-7347-2010, 2010.

Mao, J., Ren, X., Brune, W. H., Olson, J. R., Crawford, J. H., Fried, A., Huey, L. G., Cohen, R. C., Heikes, B., Singh, H. B., Blake, D. R., Sachse, G. W., Diskin, G. S., Hall, S. R., and Shetter, R. E.: Airborne measurement of $\mathrm{OH}$ reactivity during INTEX-B, Atmos. Chem. Phys., 9, 163-173, doi:10.5194/acp-9-163-2009, 2009.
Mari, C. H., Cailley, G., Corre, L., Saunois, M., Attié, J. L., Thouret, V., and Stohl, A.: Tracing biomass burning plumes from the Southern Hemisphere during the AMMA 2006 wet season experiment, Atmos. Chem. Phys., 8, 3951-3961, doi:10.5194/acp-8-3951-2008, 2008.

Martinez, M., Harder, H., Kubistin, D., Rudolf, M., Bozem, H., Eerdekens, G., Fischer, H., Klüpfel, T., Gurk, C., Königstedt, R., Parchatka, U., Schiller, C. L., Stickler, A., Williams, J., and Lelieveld, J.: Hydroxyl radicals in the tropical troposphere over the Suriname rainforest: airborne measurements, Atmos. Chem. Phys., 10, 3759-3773, doi:10.5194/acp-10-3759-2010, 2010.

Mauldin, R. L., Tanner, D. J., and Eisele, F. L.: Measurements of $\mathrm{OH}$ during PEM-Tropics A, J. Geophys. Res.-Atmos., 104, 5817-5827, 1999.

Morita, A., Kanaya, Y., and Francisco, J. S.: Uptake of the $\mathrm{HO}_{2}$ radical by water: Molecular dynamics calculations and their implications for atmospheric modeling, J. Geophys. Res., 109, D09201, doi:10.1029/2003JD004240, 2004.

Murphy, J. G., Oram, D. E., and Reeves, C. E.: Measurements of volatile organic compounds over West Africa, Atmos. Chem. Phys., 10, 5281-5294, doi:10.5194/acp-10-5281-2010, 2010.

Olson, J. R., Crawford, J. H., Chen, G., Fried, A., Jordan, M. J. E. C. E., Sandholm, S. T., Davis, D. D., Avery, B. E. A. M. A., Barrick, J. D., Blake, D. R., Brune, W. H., Eisele, F. L., Flocke, F., Harder, H., Jacob, D. J., Lefer, Y. K. A. L., Martinez, M., Mauldin, R. L., Sachse, G. W., Shetter, R., Singh, H. B., Talbot, R. W., and Tan, D.: Testing fast photochemical theory during TRACE-P based on measurements of $\mathrm{OH}, \mathrm{HO}_{2}$ and $\mathrm{CH}_{2} \mathrm{O}$, J. Geophys. Res.-Atmos., 109, D15S10, doi:10.1029/2003JD004278, 2004.

Paulot, F., Crounse, J. D., Kjaergaard, H. G., Kurten, A., St. Clair, J. M., Seinfeld, J. H., and Wennberg, P. O.: Unexpected Epoxide Formation in the Gas-Phase Photooxidation of Isoprene, Science, 325, 730-733, doi:10.1126/science.1172910, 2009.

Peeters, J., Nguyen, T. J., and Vereecken, L.,: $\mathrm{HO}_{\mathrm{x}}$ radical regeneration in the oxidation of isoprene, Phys. Chem. Chem. Phys., 11, 5935-5939, 2009

Poisson, N., Kanakaidou, M., and Crutzen, P.: Impact of NonMethane Hydrocarbons on Tropospheric Chemistry and the Oxidizing Power of the Global Troposphere: 3-Dimensional Modelling Results, J. Atmos. Chem., 36, 157-230, 2000.

Ravishankara, A. R.: Heterogeneous and multiphase chemistry in the troposphere, Science, 276, 1058-1065, 1997.

Reeves, C. E., Formenti, P., Afif, C., Ancellet, G., Atti, J.-L., Bechara, J., Borbon, A., Cairo, F., Coe, H., Crumeyrolle, S., Fierli, F., Flamant, C., Gomes, L., Hamburger, T., Jambert, C., Law, K. S., Mari, C., Jones, R. L., Matsuki, A., Mead, M. I., Methven, J., Mills, G. P., Minikin, A., Murphy, J. G., Nielsen, J. K., Oram, D. E., Parker, D. J., Richter, A., Schlager, H., Schwarzenboeck, A., and Thouret, V.: Chemical and aerosol characterisation of the troposphere over West Africa during the monsoon period as part of AMMA, Atmos. Chem. Phys., 10, 7575-7601, doi:10.5194/acp-10-7575-2010, 2010.

Ren, X. R., Brune, W., Cantrell, C., Edwards, G., Shirley, T., Metcalf, A., and Lesher, R.: Hydroxyl and peroxy radical chemistry in a rural area of Central Pennsylvania: Observations and model comparisons, J. Atmos. Chem., 52, 231-257, 2005.

Ren, X., Olson, J. R., Crawford, J. H., Brune, W. H., Mao, J., Long, R. B., Chen, Z., Chen, G., Avery, M. A., Sachse, G. W., Bar- 
rick, J. D., Diskin, G. S., Huey, L. G., Fried, A., Cohen, R. C., Heikes, B., Wennberg, P. O., Singh, H. B., Blake, D. R., and Shetter, R. E.: $\mathrm{HO}_{\mathrm{x}}$ chemistry during INTEX-A 2004: Observation, model calculation, and comparison with previous studies, J. Geophys. Res., 113, D05310, doi:10.1029/2007JD009166, 2008.

Rohrer, F. and Berresheim, H.: Strong correlation between levels of tropospheric hydroxyl radicals and solar ultraviolet radiation, Nature, 442, 184-187, 2006.

Sander, S. P., Friedl, R. R., Golden, D. M., Kurylo, M. J., Moortgat, C. K., Keller-Rudek, H., Wine, P. H., Ravishankara, A. R., Kolb, C. E., Molina, M. J., Finlayson-Pitts, B. J., Orkin, V. L., and Huie, R. E.: Chemical kinetics and photochemical data for use in stratospheric studies, Evaluation number 15, NASA Jet Propulsion Laboratory, Publication 06-2, 2006.

Saunders, S. M., Jenkin, M. E., Derwent, R. G., and Pilling, M. J.: Protocol for the development of the Master Chemical Mechanism, MCM v3 (Part A): tropospheric degradation of nonaromatic volatile organic compounds, Atmos. Chem. Phys., 3, 161-180, doi:10.5194/acp-3-161-2003, 2003.

Saunois, M., Reeves, C. E., Mari, C. H., Murphy, J. G., Stewart, D. J., Mills, G. P., Oram, D. E., and Purvis, R. M.: Factors controlling the distribution of ozone in the West African lower troposphere during the AMMA (African Monsoon Multidisciplinary Analysis) wet season campaign, Atmos. Chem. Phys., 9, 61356155, doi:10.5194/acp-9-6135-2009, 2009.

Schwartz, S. E.: Gas- and Aqueous-Phase Chemistry of $\mathrm{HO}_{2}$ in Liquid Water Clouds, J. Geophys. Res., 89, 11589-11598, 1984.

Smith, S. C., Lee, J. D., Bloss, W. J., Johnson, G. P., Ingham, T., and Heard, D. E.: Concentrations of $\mathrm{OH}$ and $\mathrm{HO}_{2}$ radicals during NAMBLEX: measurements and steady state analysis, Atmos. Chem. Phys., 6, 1435-1453, doi:10.5194/acp-6-1435-2006, 2006.

Spivakovsky, C. M., Logan, J. A., Montzka, S. A., Balkanski, Y. J., Foreman-Fowler, M., Jones, D. B. A., Horowitz, L. W., Fusco, A. C., Brenninkmeijer, C. A. M., Prather, M. J., Wofsy, S. C., and McElroy, M. B.: Three-dimensional climatological distribution of tropospheric $\mathrm{OH}$ : Update and evaluation, J. Geophys. Res.Atmos., 105, 8931-8980, 2000.

Stevens, P. S., Mather, J. H., and Brune, W. H.: Measurement of Tropospheric $\mathrm{OH}$ and $\mathrm{HO}_{2}$ by Laser-Induced Fluorescence at Low-Pressure, J. Geophys. Res.-Atmos., 99, 3543-3557, 1994.

Stewart, D. J., Taylor, C. M., Reeves, C. E., and McQuaid, J. B.: Biogenic nitrogen oxide emissions from soils: impact on $\mathrm{NO}_{\mathrm{x}}$ and ozone over west Africa during AMMA (African Monsoon Multidisciplinary Analysis): observational study, Atmos. Chem. Phys., 8, 2285-2297, doi:10.5194/acp-8-2285-2008, 2008.

Stone, D., Evans, M. J., Commane, R., Ingham, T., Floquet, C. F. A., McQuaid, J. B., Brookes, D. M., Monks, P. S., Purvis, R., Hamilton, J., Hopkins, J., Lee, J., Lewis, A. C., Stewart, D., Murphy, J., Mills, G., Oram, D., Reeves, C. E., and Heard, D. E.: $\mathrm{HO}_{\mathrm{x}}$ observations over West Africa during AMMA: impact of isoprene and $\mathrm{NO}_{\mathrm{x}}$, Atmos. Chem. Phys. Discuss., 10, 17029 17072, doi:10.5194/acpd-10-17029-2010, 2010.
Tan, D., Faloona, I., Simpas, J. B., Brune, W., Olson, J., Crawford, J., Avery, M., Sachse, G., Vay, S., Sandholm, S., Guan, H. W., Vaughn, T., Mastromarino, J., Heikes, B., Snow, J., Podolske, J., and Singh, $\mathrm{H} .: \mathrm{OH}$ and $\mathrm{HO}_{2}$ in the tropical Pacific: Results from PEM-Tropics B, J. Geophys. Res.-Atmos., 106, 32667-32681, 2001.

Thouret, V., Saunois, M., Minga, A., Mariscal, A., Sauvage, B., Solete, A., Agbangla, D., Nédélec, P., Mari, C., Reeves, C. E., and Schlager, H.: An overview of two years of ozone radio soundings over Cotonou as part of AMMA, Atmos. Chem. Phys., 9, 6157-6174, doi:10.5194/acp-9-6157-2009, 2009.

Tilgner, A., Majdik, Z., Sehili, A. M., Simmel, M., Wolke, R., and Herrmann, H.: SPACCIM: Simulations of the multiphase chemistry occurring in the FEBUKO hill cap cloud experiments, Atmos. Environ., 39, 4389-4401, 2005.

von Kuhlmann, R., Lawrence, M. G., Pöschl, U., and Crutzen, P. J.: Sensitivities in global scale modeling of isoprene, Atmos. Chem. Phys., 4, 1-17, doi:10.5194/acp-4-1-2004, 2004.

Wallace, J. M. and Hobbs, P. V.: Atmospheric Science: An Introductory Survey, Academic Press, 2002.

Weinstock, B.: Carbon monoxide: Residence time in the atmosphere, Science, 168, 224-225, 1969.

Wennberg, P. O., Cohen, R. C., Hazen, N. L., Lapson, L. B., Allen, N. T., Hanisco, T. F., Oliver, J. F., Lanham, N. W., Demusz, J. N., and Anderson, J. G.: Aircraft-borne laser induced fluorescence instrument for the in situ detection of hydroxyl and hydroperoxy radicals, Rev. Sci. Instrum., 65, 1858-1876, 1994.

Whalley, L. K., Baeza-Romero, M. T., George, I., Brooks, B., and Heard, D. E.: Do ambient aerosols influence the sensitivity of laser-induced fluorescence instruments for the measurement of tropospheric $\mathrm{OH}$ and $\mathrm{HO}_{2}$ radicals?, Atmos. Meas. Tech. Discuss., in preparations, 2010.

Whalley, L. K., Furneaux, K. L., Goddard, A., Lee, J. D., Mahajan, A., Oetjen, H., Read, K. A., Kaaden, N., Carpenter, L. J., Lewis, A. C., Plane, J. M. C., Saltzman, E. S., Wiedensohler, A., and Heard, D. E.: The chemistry of $\mathrm{OH}$ and $\mathrm{HO}_{2}$ radicals in the boundary layer over the tropical Atlantic Ocean, Atmos. Chem. Phys., 10, 1555-1576, doi:10.5194/acp-10-1555-2010, 2010.

Whalley, L. K., Furneaux, K. L., Gravestock, T., Atkinson, H. M., Bale, C. S. E., Ingham, T., Bloss, W. J., and Heard, D. E.: Detection of Iodine Monoxide Radicals in the Marine Boundary Layer using Laser Induced Fluorescence Spectroscopy, J. Atmos. Chem., 58, 19-39, 2007. 